\title{
Circumscribing Vellozia hirsuta and V. tubiflora (Velloziaceae)
}

\author{
Renato de Mello-Silva ${ }^{1}$
}

Received: 06.06.2008; accepted: 19.08.2010

\begin{abstract}
Circumscribing Vellozia hirsuta and V. tubiflora (Velloziaceae)). Vellozia hirsuta and V. tubiflora belonged to Vellozia sect. Radia, a poliphyletic taxon. Due to different choices of characters for delimiting the species, from 21 species formelly included in the section, only three are now recognised. The hypanthial tube longer than ovary, and deciduous in fruit, distinguishes $V$. hirsuta and V. tubiflora from all other Velloziaceae. Although consistently delimited, they exhibit wide intraspecific variation. Thus, $V$. hirsuta encompasses four taxonomic synonyms, and V. tubiflora, 19. On the other hand, the many different populations of both species lead to the recognition of 14 morphological patterns within $V$. hirsuta and eight within $V$. tubiflora, although those patterns cannot receive taxonomic status.
\end{abstract}

Key words: patterns, populations, synonymy, taxonomic delimitation

RESUMO - (Circunscrição de Vellozia hirsuta e V. tubiflora (Velloziaceae)). Vellozia hirsuta e V. tubiflora pertenceram a Vellozia sect. Radia, um táxon polifilético. No entanto, das 21 espécies incluídas na secção, somente três são reconhecidas, devido aos diferentes caracteres utilizados para delimitar as espécies. O tubo do hipanto mais longo que o ovário e decíduo na frutificação distingue $V$. hirsuta e $V$. tubiflora de todas as demais espécies de Velloziaceae. Embora consistentemente delimitadas, ambas exibem grande variação intra-específica. Assim, V. hirsuta engloba quatro sinônimos taxonômicos e V. tubiflora, 19. Por outro lado, as diferentes populações de ambas as espécies levam ao reconhecimento de 14 padrões morfológicos em $V$. hirsuta e oito em $V$. tubiflora, embora esses padrões não possam receber status taxonômico.

Palavras-chave: delimitação taxonômica, padrões, populações, sinônimos

\section{Introduction}

Vellozia hirsuta and $V$. tubiflora belonged to the former Vellozia sect. Radia, defined as being composed of species having flat leaves, with almost always distinct grooves on the abaxial side, tepals fused into a long tube, and more than six stamens (Smith \& Ayensu 1976). Of these attributes, the long hypanthium tube is the most characteristic and has also been used by Menezes (1980) to define the section. Cladistic analyses (Behnke et al. 2000, Mello-Silva 2000, 2005) suggested that Vellozia sect. Radia should be a polyphyletic group. In Mello-Silva $(2000,2005)$ V. hirsuta and V. tubiflora emerged as closed related species, although in MelloSilva et al. (unpublished data) they belong to rather distinct clades. From a total of 21 species admitted to that section by Smith \& Ayensu (1976), only four were recognized by Mello-Silva (2000). These contrasting positions reflect different opinions about the aspects to be addressed in the delimitation of the species in Velloziaceae. Non-variable characters have often been ignored in favour of others more prone to variation. Smith \& Ayensu (1976) used the indumentum, the dimensions of the pedicel, and the hypanthium tube as the basis to distinguish the various species within the section Radia, although these characters may not be very consistent with species limits, nor with different populations of the same species (Mello-Silva 1990, 1995). An example of this situation is the synonymization of $V$. leucanthos with $V$. cachimbensis, by Smith \& Ayensu (1976), based on similarities such as habit and vestiture, while neglecting characters such as aquiferous parenchyma and phloem strands, which are now used to merge those species into $V$. hirsuta and $V$. tubiflora, respectively. Their variation is here characterized and discussed in a similar, although

1. Universidade de São Paulo, Departamento de Botânica, Rua do Matão 277, edifício Sobre-as-Ondas, 05508-090 São Paulo, SP, Brasil.mellosil@usp.br 
much more encompassing, study that has been done for $V$. hirsuta solely (Mello-Silva 1990). This paper also provides an identification key, descriptions, synonymy, typifications, illustrations, phenology, and geographic distribution of the species.

\section{Material and methods}

Morphological studies where conducted using herbarium specimens as well as some spirit collections. Studied material and the herbaria where they are deposited are arranged in geographical order, from North to South. Herbarium specimens not examined are indicated by n.v. (non vidi). Herbarium acronyms follow Holmgren \& Holmgren (1998). Transversal sections of the median portion of the leaf blades and pedicels from dried specimens were made employing a hand-held razor blade. Sections were stained with oyster-blue and basic fucsin according to Roeser (1972) and adapted by Luque et al. (1996). Median portion of leaf blades and seeds were mounted on aluminium stubs, coated with gold, and examined with a scanning electron microscope Zeiss DSM 940. Drawings were done in pen-and-ink, with the aid of a Wild M8 stereomicroscope equipped with a camera lucida. Type specimens (holotypes and/or isotypes) of all names were examined, except of $V$. markgrafii and $V$. macrosiphonia, which were not located, and of $V$. dumitiana. From this last one, paratypes were examined.

\section{Results and Discussion}

Characters circumscribing Vellozia hirsuta and $V$. tubifora are those also used in cladistic analyses (Mello-Silva 2000, 2005). Vellozia hirsuta is delimited by one phloem strand, and solitary flowers; $V$. tubiflora by smooth subsidiary cells in stomata, aquiferous hypodermis extending to bundle sheaths and furrows, spiral thickenings in exotesta of seeds absent (Sousa 2005), and a sclerified belt in pedicels. The hypanthial tube always longer than ovary, and deciduous in fruit, distinguishes both species from all other Velloziaceae. Although consistently delimited, $V$. hirsuta and V. tubiflora exhibit a wide infraspecific variation. They comprehend many different and more or less isolated populations, distributed over a large area, and genetic exchange between populations is very improbable. The populations are found on isolated mountains, what may have allowed the appearance and fixation of distinctive characteristics in each group, increasing their diversity. These differences occur in a reticulated pattern within the populations, and leads to the recognition of two complex species. The only other option would be their fragmentation into a number of species, a majority with a restricted distribution, whose delimitations would be problematic, if not impossible.

\section{Identification key}

1. Stamens 6 or, if more, hypanthial tube shorter than or equal to ovary or, if longer, then hypanthium persistent in fruit all other Velloziaceae

1. Stamens 9-24, hypanthial tube always longer than ovary (e.g. figure 4D) and deciduous in fruit (e.g. figure 4A)

2. Aquiferous hypodermis extending to bundle sheaths only (figure 1A, C), phloem strands one (figure 1G), flowers always solitary, pedicel with 12-24 vascular bundles and belt of sclerified cells absent (figure 1I), spiral thickenings in exotesta of seeds present (figure $1 \mathrm{M}, \mathrm{N}, \mathrm{O}$ ) (Minas Gerais, Espinhaço range and disjunctions to Pedra Azul. Bahia, southern portion of Espinhaço range and disjunctions to Jequié, parapatric to $V$. tubiflora, figure 2) ...... V. hirsuta

2. Aquiferous hypodermis extending to bundle sheaths and furrows (figure 1B, D-F), phloem strands two (figure $1 \mathrm{H}$ ), flowers solitary or grouped, pedicel with 6 vascular bundles and belt of sclerified cells present (figure 1J), spiral thickenings in exotesta of seeds absent (figure 1K, L) (São Paulo, Brazil, to Panama, Central America, parapatric to $V$. hirsuta, figure 2) ...... V. tubiflora

Vellozia hirsuta Goethart \& Henrard in Henrard, Blumea 2: 374. 1937. Type: BRAZIL. MinAS GERAIS: Diamantina, Birybiry près de Diamantina dans le campo, 24-III-1892, A.F.M. Glaziou 19924 (holotype $\mathrm{L}$, isotypes $\mathrm{C}, \mathrm{K}, \mathrm{P}$ ).

$=$ Vellozia leucanthos Goethart \& Henrard in Henrard, Blumea 2: 375. 1937. Type: BRAZIL. Minas Gerais: Catas Altas, Serra do Inficionado près de Caraça, dans le campo, 10-VII-1883, A.F.M. Glaziou 15674 (holotype L, isotypes C, $\mathrm{K}, \mathrm{MO}, \mathrm{P})$, syn. nov.

= Vellozia maguirei L.B. Sm., Contr. U.S. Nat. Herb. 35: 267, pl. 5. 1962. Type: BRAZIL. Minas Gerais: 49 miles from Diamantina, elev. 


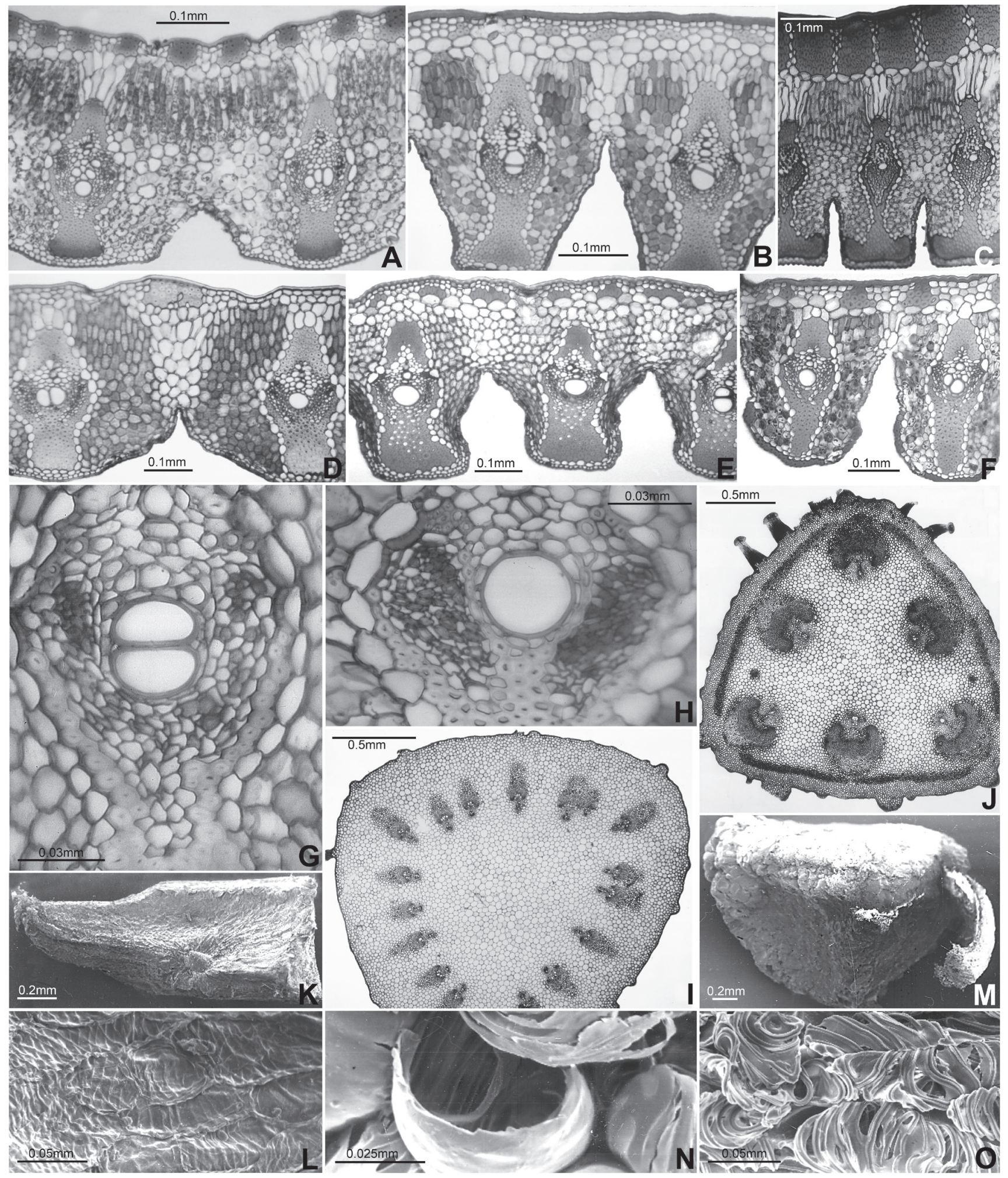

Figure 1. Characters distinguishing V. hirsuta (A, C, G, I, M-O) and V. tubiflora (B, D-F, H, J-L). A-H. Transverse sections of leaves. A. Glaziou 15674. B. Philipson 2320. C. Mello-Silva 508. D. Rosa 2018. E. Idrobo 632. F. Glaziou 22218. G. Glaziou 19924. H. Schultes 5741. I-J. Transverse sections of pedicel. I. Mello-Silva 465. J. Cavalcanti 405. K-O. Seeds showing detail of testa. K-L. Williams 12974. M-N. Mello-Silva 461. O. Mello-Silva CFCR10794. 
3800 feet, 22-XII-1959, B. Maguire et al. 44742 (holotype US, isotypes R, RB), syn. nov.

= Vellozia markgrafii Schulze-Menz in Markgraf, Notizbl. Bot. Gart. Berlin-Dahlem 15: 216. 1940. Type: BRAZIL. Minas Gerais: Francisco Sá, Gebirge östlich von Montes Claros, Serra de São Calixto, $13 \mathrm{~km}$ nordöstl. vom Gasthaus Flamingo, elev. 1000 ("100") m, 11-XI-1938, F. Markgraf et al. 3373 (holotype, B?, not found), syn. nov.

$=$ Vellozia riedeliana Goethart \& Henrard in Henrard, Blumea 2: 379. 1937. Type: BRAZIL. Minas Gerais: Serra da Lapa, XI-1824, L. Riedel 1051 (lectotype L, here designated, probable isolectotype LE), syn. nov.

Figures 1A, C, G, I, M-O, 2, 3-6, 11A

Plants caespitose or solitary. Stem $1.5-120 \mathrm{~cm}$ long, 0.4-5 cm diam. at apex, entire or few-branched, rarely much-branched. Living leaves 3-16 in each branch, tristichous. Leaf sheaths adaxially glabrous, abaxially densely lanate to lanate-tomentose to glabrescens, or glabrous at the base and glabrescens at the apex; apex curved or straight, entire or lacerate. Leaf lamina (2-)6-37 cm long, 1.5-15 mm broad, linear-triangular, plane or arcuate, twisted, in sicco either revolute or conduplicate near midrib and plane near margins, at least at distal portion, rarely involute, erect or erect to spreading, green, deciduous or marcescent and reflexed, densely to sparsely covered with trichomes of varying lengths up to $1 \mathrm{~cm}$, these flat, entire, branching or in fascicles, larger and more densely disposed on the abaxial surface and towards the base, otherwise the lamina lanate on the margins and on central nerve at abaxial surface or glabrescens or glabrous; either very viscous to viscous to not viscous at all, odoriferous or not; margins entire, hardly to clearly thickened, indumentum similar to that of the lamina; apex generally long, rarely shortattenuate. Flower 1 per branch, odoriferous. Pedicel 1-21 cm long, 1-3 mm diam., trigonous, shorter than the leaves, rarely longer (Mello-Silva 454), evident, sometimes hidden amongst the leaves and sheaths, and then up to $4 \mathrm{~cm}$ long, the flower appearing sessile; during fructification either of the same length or expanded up to $7.5 \mathrm{~cm}$ long and c. $4 \mathrm{~mm}$ diam., green, lighter and smooth towards base, bearing small glandular emergences in the apical half, sometimes totally smooth. Hypanthium, in the ovary region, oblong-trigonous, with attenuate angles, 5-20 $\mathrm{mm}$ long, 2-7 mm broad, green, densely covered with emergences, these glandular-stipitate with concave, truncate, umbonate or subulate apex, sometimes subulate or densely tomentose. Hypanthial tube 2.5$11 \mathrm{~cm}$ long, 1-4 mm diam. at base, 2-7 mm diam. at apex, white to slightly purplish, green or greenish purple at base, with emergences similar to those of the ovary region but smaller and sparsely distributed at the base and the region continuous to the external tepals. Tepals 4.5-7.5 cm long, $1-3 \mathrm{~cm}$ broad, oblong-elliptical, arched and spreading in the apical half, white, rarely purple, the outermost bearing emergences similar to that of the hypanthial tube on the proximal abaxial surface and on the midrib, adaxial surface glabrous; the innermost glabrous on both surfaces or with the emergences at the base of abaxial surface. Stamens 9-24, all equal, exserted from tube; filaments c. $2.5-3 \mathrm{~cm}$ long, white to greenish; anthers 1-3 cm long, yellow to pale-yellow, latrorse; staminal appendages absent. Style 5-12.5 $\mathrm{cm}$ long, white to purplish-white, protruding beyond the stamens; stigma 3-6 mm diam., yellow to white. Capsule 1-3.3 cm long, 6-25 mm diam., ellipsoid to oblong-trigonous to suborbicular-trigonous to spheroid, loculicidal, green to greenish-purple when immature, chestnut brown at maturity, at first covered by the hypanthium, with emergences like those of the flower, thicker or not, the hypanthium later caducous. Seeds numerous, 2-3 mm long, cinereous, exotesta with spiral thickenings.

Foliar and pedicellar anatomy (figures 1A, C, G, I, 3) - Lamina dorsiventral. Furrows c. 1/3-1/4 of the thickness of the lamina, rarely absent, smooth. Cuticle thicker on the adaxial surface. Adaxial epidermis pluriseriate (types 1,2 and 3) or uniseriate (types 4 and 5), abaxial uniseriate. Stomata always present on the abaxial surface, usually inside the furrows; on the adaxial surface present either on entire surface (type 5), or only on the inner half of lamina (types 2, 3 and 4) or only near the midrib to absent (type 1). Aquiferous hypodermis of the adaxial surface 1-2-seriate, extending to endodermis as aquiferous parenchyma. Palisade parenchyma 3-4 cell layers thick, abaxially merging with spongy parenchyma. Fibro-vascular bundles surrounded by endodermis as leaf bundle sheath. 1-2 larger vessels present in each bundle. Phloem strand 1, V-shape beneath the xylem. Pericyclic fibres extending adaxially to the aquiferous parenchyma and abaxially to (or nearly to) the hypodermis (in Mello-Silva 508, laterally enlarged at base, reaching the furrows [figure 1C]). Fibres strands (1-)3-6(-10) cell layer thick on all adaxial surface (type 1) or (1-)2-3 cell layer thick 
present on the outer half of lamina (types 2 and 3) or absent (types 4 and 5); fibres strands (1-)2-3 cell layer thick at the entrances of the furrows (types 1 and 4). Pedicel triangular in transverse section. Fibro-vascular bundles 12-24. Belt of sclerified cells absent.

Specimens examined: BRAZIL. BAHIA: Macaúbas, Hatschbach 78613 (MBM, SPF); Caetité, Taylor 1536 (CEPEC, K, SPF); Brejinho das Ametistas, Mello-Silva 3218 (BHCB, HUEFS, NY, SPF); Roque CFCR14943 (HUEFS, IPA, K, MBM, MO, NY, SPF, UB); between Vitória da Conquista and Jequié, cultivated on Rio de Janeiro, Menezes s.n. (SPF 34204); Cordeiros, Araújo 173 (HRB, RB); MelloSilva 3206 (BHCB, HUEFS, K, SPF); MinAs GERAIS: Espinosa, Sakuragui CFCR15062 (K, SPF); São João do Paraíso, Mello-Silva 3205 (BHCB, G, NY, SPF); Mato Verde, Mello-Silva 461 (K, MBM, NY, SPF, UEC), 462 (BHCB, CTES, F, K, MBM, NY, RB, SPF), 3220 (B, BHCB, NY, SPF), 3221 (BHCB, SPF); Sakuragui CFCR 15143 (K, SPF); Rio Pardo de Minas, Assis 332 (HRB); Pedra Azul, Hatschbach 44286 (C, M, MBM); Jequitinhonha, Magalhães 17581 (HB, US n.v.); Grão-Mogol, Carvalho 808 (SPF); Ghillány s.n. (HB n.v., US 2787508); Guillány s.n. (HB n.v., US 2787514); Hatschbach 41274 (B, C, HB, INPA, MBM, MO, NY, SPF, UEC, US n.v.), 41532 (C, COL, INPA, MBM, NY, SPF, US n.v.), 41591 (INPA, MBM, NY, US n.v.), 42860 (MBM, US), 42924 (MBM, US n.v.), 55036 (BR, C, MBM n.v., MO n.v., S, SPF), 55088 (MBM n.v., S, SPF, U); Irwin 23334 (NY, UB); 23377 (NY n.v., US); Lopes 46 (SPF), 47 (SPF); Mello-Silva 444 (COL, G, MBM, MO, SPF, UB), 454 (COL, G, K, MBM, SP, SPF, UB, US), 465 (BHCB, COL, F, G, HUEFS, K, MBM, MO, NY, RB, SPF), 466 (F, SPF), 470 (G, HUEFS, MO, R, SPF), 473 (HUEFS, SPF, UEC, US), 475 (G, SPF), 476 (MBM, NY, SPF), 477 (G, SPF), 478 (SPF), 1421 (G, SP, SPF), 2559 (B, L, SPF), 3202 (BHCB, MBM, RB, SPF), 3203 (BHCB, CTES, G, SPF), 3204 (BHCB, M, RB, SPF), CFCR8844 (F, K, RB, SPF), CFCR8877 (F, G, K, MBM, RB, SPF), CFCR8976 (BHCB, K, MBM, NY, SPF), CFCR8991 (F, K, MBM, SP, SPF), CFCR9662 (NY, SPF, UB, UEC), CFCR9665 (F, K, SPF), CFCR10019 (BHCB, F, G, K, MBM, MO, SP, SPF), CFCR10794 (F, MBM, SPF), CFCR11577 (F, K, RB 2 sheets, SP, SPF), CFCR11588 (BHCB, F, G, K, SPF); Menezes 1115 (F, K, SPF); Simonis CFCR4091 (SPF, U n.v.); Windisch 346 (HB); Cristália, Mello-Silva 484 (SPF), CFCR8887 (K, MBM, SPF); Hatschbach 55005 (C,
MBM n.v., SPF); Botumirim, Carvalho 715 (SPF); Mello-Silva 508 (BHCB, K, MBM, SPF), 515 (CTES, G, K, MBM, MO, RB, SPF, UB, US), 662 (CTES, MBM, SPF), 1452 (K, MBM, NY, SP, SPF, UB, W), 1453 (SP, SPF), 3191 (BHCB, MBM, RB, SPF), 3193 (BHCB, F, SPF, US), 3196 (B, BHCB, RB, SPF); Rapini 764 (G, SP, SPF); Rivadavia Lopes 338 (SPF); Windisch 335 (HB), 337 (HB); estrada Botumirim - Adão Colares, Mello-Silva 739 (CTES, F, K, MBM, NY, SPF), 3197 (BHCB, CEN, L, SPF); Turmalina, estrada Itacambira-Caçaratiba, Mello-Silva 1503 (SPF); Juramento, Mello-Silva 3180 (BHCB, NY, SPF, US); Itacambira, MelloSilva 520 (G, MBM, MO, SPF), 526 (CTES, MO, SPF), 629 (CTES, K, MBM, SPF), 629a (CTES, SPF), 635 (CTES, G, K, MBM, MO, NY, RB, SPF, U, UB, US), 1501 (SP, SPF), 3185 (BHCB, SPF), 3189 (BHCB, RB, SPF, US), 3190 (BHCB, SPF), CFCR9109 (BHCB, F, K, SPF), CFCR9121 (K, NY, SP, SPF); Menezes 1325 (SPF); Pirani 2261 (K, NY, SPF); Rivadavia Lopes 316 (SPF); between Itaobim and Araçuaí, Menezes 1022 (F, K, MBM, SPF) (B3); Joaquim Felício, Mello-Silva 3222 (BHCB, RB, SPF); Souza CFCR15380 (SPF); Wanderley 1378 \& Kral 75382 (SP, VDB n.v.); Buenópolis, Mello-Silva 285 (CTES, SPF); Itamarandiba, Mello Barreto 9984 (BHCB n.v., SP); Felício do Santos, Viana 2876 (BHCB, SPF); Rio Vermelho, MelloSilva 419 (BHCB, NY, SPF), CFCR5459 (BHCB, F, G, K, MBM, RB, SPF), CFCR5497 (F, K, MBM, SPF, UB); Diamantina, Arbo 5051 (BHCB, CTES, K, SPF); Braga 409 (BHCB n.v., SPF); Duarte 8522 \& Pereira 9292 (HB, RB, SPF); Hatschbach 28996 (MBM n.v., US); Giulietti CFCR2376 (F, G, K, MBM, RB, SPF), CFCR2466 (F, G, K 2 sheets, MBM, RB, SPF); Graff 83 (R); Hatschbach 36493 (MBM, US n.v.); Hensold CFCR 3184 (F, K, SPF); Mello Barreto 9538 (BHCB n.v., SP), 9814 (BHCB n.v., SP); MelloSilva 407 (BHCB, K, MO, SPF, UB), 409 (F, SPF), 2698 (SPF, RB), CFCR8606 (K, MBM, NY, SPF); Menezes 556 (BHCB, F, K, SPF), 1039 (F, K, MBM, SPF); Riedel 1421 (K, LE); Shepherd 3932 (UEC); Smith 15999 (HB, MBM, US); Vitta CFCR11905 (K, SPF); Gouveia, Giulietti CFCR2182 (BHCB, G, HUEFS, NY, SP, SPF); Hatschbach 28093 (C, HB, MBM, S, US); Mello-Silva 391 (BHCB, K, NY, $\mathrm{SPF}), 3176$ (BHCB, RB, SPF); Serro, Benko-Iseppon 317 (SPF, UFP); Hatschbach 28965 \& Smith 15983 (MBM, NY, US); Presidente Kubitschek, Mello-Silva 3177 (BHCB, K, NY, SPF); Menezes CFCR8817 (SPF), CFCR11936 (SPF); Conceição do Mato 
Dentro, Menezes 344 (BHCB, SPF); Without precise location: cultivated on Rio de Janeiro, Menezes 780 (SPF), 903 (SPF), 1225 (SPF).

Vellozia hirsuta occurs in the Espinhaço range in Brazil, from the northern part of the Serra do Cipó to Espinosa, in Minas Gerais State. Some disjunct populations occur near Catas Altas, Jequitinhonha and Pedra Azul, in Minas Gerais, and near Cordeiros, Caetité, Macaúbas, and Jequié, in Bahia State. This species is found either in the high mountains, covering large rocky surfaces, or on smaller rock outcrops in the midst of arboreal or shrub vegetation in regions of cerrado and caatinga vegetation (figure 2).

Mello-Silva (1990) recognized the existence of six patterns in Vellozia hirsuta, in a combination of five diferent types of leaf anatomy (figure 3) and three types of vegetative morphology. Nevertheless, those anatomical types are not fixed. Analyses of 4,500 leaves from approximately 800 individuals from 18 populations (table 1) reveal intermediate types between anatomical types 1 and 2 (figure 3C) and between anatomical types 3 and 5 (figure $3 \mathrm{~K}$ ). These variations occur principally in Grão-Mogol, where populations with different types are in close contact. Additionally, two nearby populations in Diamantina demonstrate a certain degree of variation.
Populations showing type 1 appear to be less subject to variation, while type 5 populations are the most variable. This may be due to the greater isolation of the majority of type 1 populations. In addition, one population with plants of type 5 (Mello-Silva 454), which is geographically isolated, demonstrates a low level of variation, suggesting that greater variation is the result of greater genetic flux among populations. Within the same leaf, the type of leaf anatomy is always uniform (figure $3 \mathrm{~A}, \mathrm{~B}, \mathrm{H}-\mathrm{J}$ ) although different leaves on the same individual can show different types. Two plants from Mello-Silva 465, which showed the highest degree of variation, had all their leaves examined. The first of these plants had four leaves with anatomical type 3 , nine leaves that had types intermediate between 3 and 5, and seven leaves having type 5 . The second individual had three leaves with intermediate types between 3 and 5, and seven leaves with type 5 . Another leaf from Windisch 337, the only collection which was found to possess anatomical type 4 (Mello-Silva 1990), showed one fibre bundle in the adaxial epidermis, characterizing a intermediate type between 2 and 4 .

Thus, there are populations that have anatomical types and external morphology intermediate between the major patterns established by Mello-Silva (1990),

Table 1. Foliar anatomical types of 4500 examined leaves from 18 populations and of Vellozia hirsuta.

\begin{tabular}{|c|c|c|c|c|c|c|c|c|}
\hline \multirow[t]{2}{*}{ Collections } & \multirow[t]{2}{*}{ Locality } & \multirow[t]{2}{*}{ Leaves } & \multicolumn{6}{|c|}{ Foliar anatomic types } \\
\hline & & & 1 & $1-2$ & 2 & 3 & $3-5$ & 5 \\
\hline Mello-Silva 391 & Gouveia & 200 & 200 & & & & & \\
\hline Mello-Silva 407 & Diamantina & 200 & 89 & 84 & 27 & & & \\
\hline Mello-Silva 409 & Diamantina & 200 & 182 & 18 & & & & \\
\hline Mello-Silva 419 & Pedra Menina & 200 & 200 & & & & & \\
\hline Mello-Silva 526 & Itacambira & 200 & 200 & & & & & \\
\hline Mello-Silva 515 & Botumirim & 800 & 800 & & & & & \\
\hline Mello-Silva 484 & Cristália & 200 & 200 & & & & & \\
\hline Mello-Silva 444 & Grão-Mogol & 200 & 200 & & & & & \\
\hline Mello-Silva 476 & Grão-Mogol & 140 & 140 & & & & & \\
\hline Mello-Silva 473 & Grão-Mogol & 200 & 200 & & & & & \\
\hline Mello-Silva 466 & Grão-Mogol & 200 & 196 & 4 & & & & \\
\hline Mello-Silva 475 & Grão-Mogol & 200 & & & & 200 & & \\
\hline Mello-Silva 470 & Grão-Mogol & 200 & & & & 199 & 1 & \\
\hline Mello-Silva 478 & Grão-Mogol & 200 & & & & 196 & 4 & \\
\hline Mello-Silva 477 & Grão-Mogol & 200 & & & & 121 & 62 & 17 \\
\hline Mello-Silva 465 & Grão-Mogol & 560 & & & & 55 & 144 & 361 \\
\hline Mello-Silva 454 & Grão-Mogol & 200 & & & & & 10 & 190 \\
\hline Mello-Silva 461 & Mato Verde & 200 & 200 & & & & & \\
\hline Total & & 4500 & 2807 & 106 & 27 & 771 & 221 & 568 \\
\hline
\end{tabular}




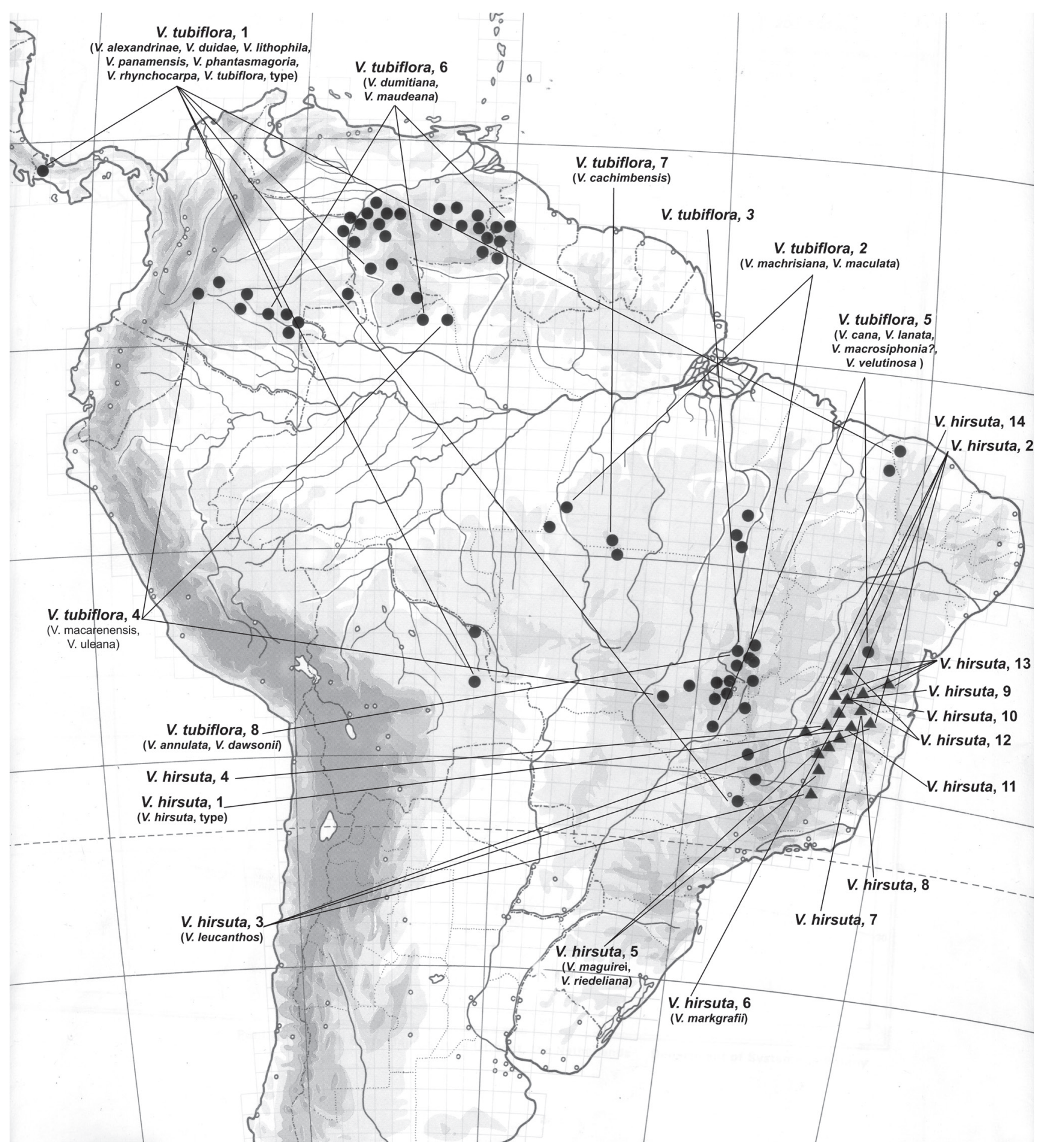

Figure 2. Geographical distribution of $V$. hirsuta $(\mathbf{A})$ and $V$. tubiflora $(\mathbf{O})$ in Central and South Americas, showing occurrence of the different patterns (numbers) of each species. Base map modified from Flora Neotropica base map, The State University of Utrecht, the Netherlands. 
and whose geographical distribution indicates a reticulated pattern of interrelations. Fourteen patterns of variation can be recognized, which are reasonably distinct, although non-discrete. These patterns could be distributed into two more or less distinct and sympatric assemblages. One of these assemblages (patterns 1 to 5, bellow), which has been considered as a population complex of $V$. hirsuta (Mello-Silva 1990, 1995), inhabits the Espinhaço range from Catas Altas to Minas Gerais and Bahia border, with lateral extensions to the east, near the town of Jequitinhonha, and west to the Serra do Cabral. The other assemblage (patterns 6 to 11, bellow), which has been considered as $V$. markgrafii (Mello-Silva 1995), occupies a smaller area, stretching from the town of Itacambira to Minas Gerais and Bahia border. There are, additionally, other populations in Bahia and in northern Minas Gerais that do not fit in either of these two assemblages, in a total of 14 recognisable patterns. The patterns within each assemblage maintain almost unique characteristics. In the first assemblage, which includes the types of $V$. hirsuta, $V$. leucanthos, $V$. maguirei, and $V$. riedeliana, the dried leaves are revolute, rarely involute; the leaf blade is viscid and generally odoriferous, almost always without a well defined abscission zone; the flowers are more delicate, almost always with an evident pedicel; the hypanthium emergences are short and truncated, rarely subulate, and never covered by a tomentose indumentum. In contrast, the plants from the second assemblage, which includes the type of V. markgraffii, have leaves conduplicate near their centre and flat along the margins, rarely revolute (Mello-Silva 629), and generally more sclerified (figure 1C); neither viscous, nor odoriferous, with abscission zone almost always well defined; flowers more robust, with their pedicel almost always hidden; and hypanthium emergences either cylindrical with truncated apices, concave or umbonate, or long-subulate, often covered with a tomentose indumentum. These assemblages, whose complexity will be described below, could be classified into two distinct species (Mello-Silva 1995) were it not for the lack of universal characteristics that would allow one to distinguish them, as well as for the existence of a number of intermediate populations.

Pattern 1 - (Arbo 5051; Giulietti CFCR23761, CFCR24661; Hensold CFCR3184; Mello-Silva 407, 409, 419, CFCR5459, CFCR5497, CFCR8606; Viana 2876; figure 4A, B). The plants have long stems, reflexed and marcescent leaves, which are revolute in sicco, with golden-hirsute indumentum of very long trichomes (figure 4A). These are restricted to Gouveia and Diamantina region, mainly in Biribiri, as the type-collection of the species, Glaziou 19924. The individuals from Rio Vermelho have a very reduced stem and very short trichomes (figure 4B). The anatomical type is generally 1 but Giulietti CFCR2376 and Hensold CFCR3184 have anatomical type 2 . This pattern has been previously defined as A1 with marcescent leaves (Mello-Silva 1990).

Pattern 2 - (Benko-Iseppon 317; Braga 409; Carvalho 715, 808; Giulietti CFCR2182; Hatschbach 41274, 44286; Lopes 47; Mello-Silva 285, 391, 466, 473, 484, 515, 526, 1421, 1453, 1501, 2559, 2698, 3176, 3196, 3202, 3222, CFCR8877, CFCR8887, CFCR8991, CFCR9109; Menezes 556, 1039; Sakuragui CFCR15062, CFCR15143; Vitta CFCR11905; Windisch 337; figure 4C-F). The plants have a long stem, up to $1 \mathrm{~m}$ tall, the leaves are long, with approximately $30 \mathrm{~cm}$ long, caducous, revolute in sicco, with leaf sheaths dilacerated and with a matted appearance. This pattern has the widest geographical distribution. Their anatomical type is, in general, 1, but types 2 and 4 are also present. Individuals from Itacambira, Botumirim, Grão-Mogol and Mato Verde are generally smaller and have much longer floral pedicels (figure 4D), and those from Serra do Cabral have very short pedicels, hidden by the leaf-sheaths. Populations from Pedra Azul and Jequitinhonha have some reflexed and marcescent leaves (figure 4E). Populations from Cristália (figure 4F) are very similar to pattern 3 plants. Windisch 337 (figure 4C), classified as pattern A4 (Mello-Silva 1990), shows, besides the anatomical type 4 (figure $3 \mathrm{G}$ ), an intermediate type between 2 and 4 (figure 3E, F). This pattern has been previously defined as pattern A1 with leaves caducous (Mello-Silva 1990).

Pattern 3 - (Glaziou 15674; Mello-Silva 454, 465, 477, 1503, CFCR8844; Menezes 1022, 1115; figures $5 \mathrm{~A}-\mathrm{C})$. The smallest individuals within the species are found among the populations of this pattern. The plants generally grow in large clumps. The leaves are small, many of them reflexed and marcescent, and revolute in sicco. The plants are found in Grão-Mogol, Botumirim, Serra do Caraça (Glaziou 15674, type of $V$. leucanthos), and in the region between Itaobim and Araçuaí. The populations from Grão-Mogol show the anatomical type 5, although with some variation; the others show the anatomical type 3. Mello-Silva 454 (figure 5B, C) and 1503 have leaf blades involute in sicco, in contrast to the other collections, whose 


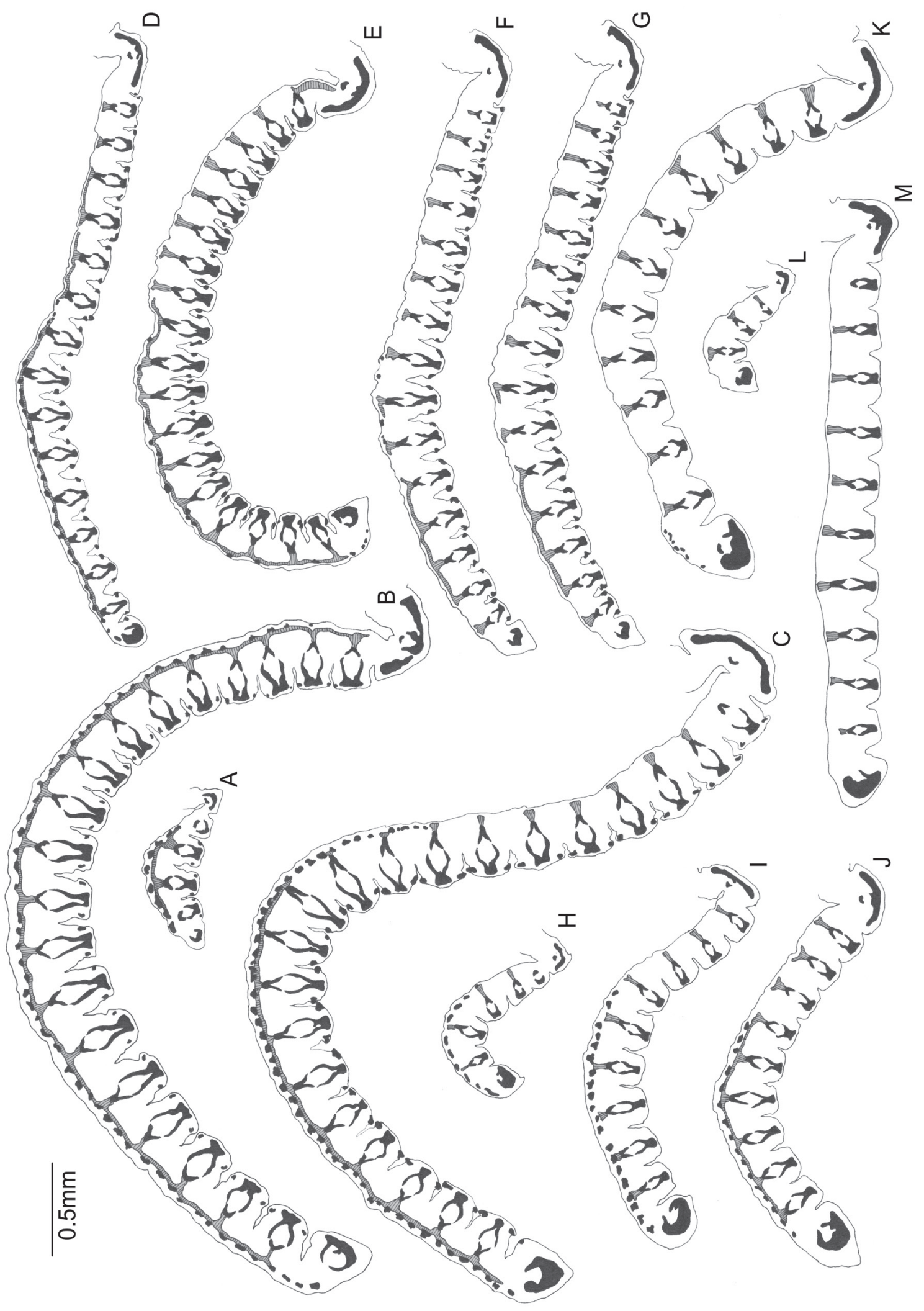

Figure 3. Foliar anatomical types of $V$. hirsuta. Transverse sections of leaves, showing the distribution of sclerenchyma, in black, and of aquiferous parenchyma, hatched. A-B. Type 1. A. Apex of lamina. B. Mid portion of lamina (Mello-Silva 484). C. Intermediate type between 1 and 2 (Mello-Silva 407). D. Type 2 (Hatschbach 28093). E-F. Intermediate types between 2 and 4 (Windisch 337). G. Type 4 (Windisch 337). H-J. Type 3. H. Apex of lamina. I. Mid portion of lamina. J. Base of lamina (Mello-Silva 470). K. Intermediate type between 3 and 5 (Mello-Silva 465). L-M. Type 5. L. Apex of lamina. M. Mid portion of lamina (Menezes 1115). 


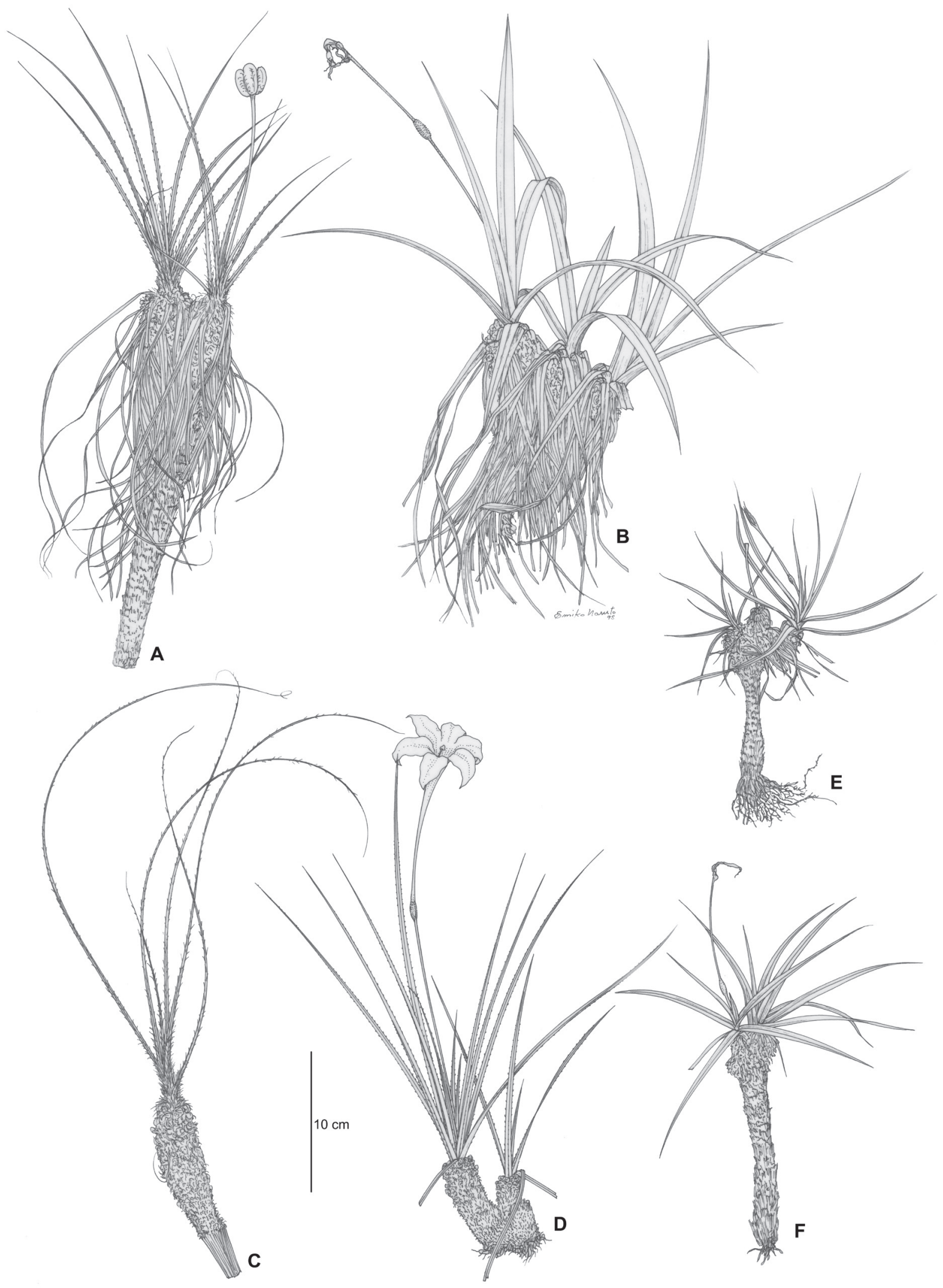

Figure 4. Patterns of V. hirsuta. A-B. Pattern 1. A. Mello-Silva 407., B. Mello-Silva CFCR5497. C-F. Pattern 2, C. Windisch 337. D. MelloSilva CFCR8877. E. Hatschbach 44286. 
dried leaves are invariably revolute. Mello-Silva 465 and 477 show leaves with an intermediate anatomical type between 3 and 5 (figure 3K). Some collections (Mello-Silva 465, CFCR8844) have intermediate individuals between those from this pattern and those from pattern 4. This pattern has been previously defined as B5 (Mello-Silva 1990).

Pattern 4 - (Ghillány US 2787508; Hatschbach 41532, 42924; Lopes 46; Mello-Silva 470, 475, 478, 3204, CFCR9665, CFCR10019, CFCR10794, CFCR11577; Menezes 780, 903, 1225; Windisch 346; figure 5D). Restricted to Grão-Mogol. The stem is thin and elegant, with recurved leaf sheaths. The leaves are usually caducous, but some are marcescent and reflexed. The large majority are of anatomical type 3. Menezes 1225, 780 and 903, from cultivated plants of uncertain origin, show pedicel variations. The first has a visible pedicel of about $5 \mathrm{~cm}$ long but the others have short, hidden pedicels, similar to many plants from patterns 6 to 11 . This pattern has been previously defined as C3 (Mello-Silva 1990).

Pattern 5 - (Maguire 44742; Mello-Silva 3177; Menezes 344, CFCR8817, CFCR11936; Riedel 1051, 1421; figure 5E). Plants from Gouveia to Conceição do Mato Dentro, characterized by small stature, up to $20 \mathrm{~cm}$ tall, small leaves, up to $15 \mathrm{~cm}$ long, revolute in sicco, with short trichomes; the flowers are short pedicellate, almost sessile, as for example, Maguire 44742 (type of $V$. maguirei) and Riedel 1051 (type of $V$. riedeliana). Their anatomical type is 1 .

Pattern 6 - (Ghillány US 2787514; Hatschbach 55005, 55036; Mello-Silva 3180, 3203, CFCR8976, CFCR9662; Simonis CFCR4091; figure 5F). The plants are from Grão-Mogol, Cristália, and Juramento. They are robust, up to $1.2 \mathrm{~m}$ tall, but smaller in Juramento, with leaf sheaths woolly, leaves glabrous or glabrescent on the adaxial side and densely silver-tomentose on the abaxial side; the very short pedicels, up to $1 \mathrm{~cm}$, are frequently hidden by the leaves. The hypanthium emergences are glandular, long, and concave at apex. The pedicel develops during fructification, reaching up to $7.5 \mathrm{~cm}$ in length.

Pattern 7 - (Mello-Silva 520, 629a, 3185, 3190, CFCR9121; Menezes 132; Pirani 2261; figure 6A). Plants from Itacambira that grow exclusively on rocky surfaces, and are less robust and more highly branched than pattern 6 . The leaf sheaths are glabrescent and more widely spaced one from another. The leaf surfaces are sparsely tomentose to glabrous on the abaxial side, and glabrous and, when dry, yellowish on the adaxial surface. The hypanthium and the floral tube are tomentose. During fruiting, the hypanthium emergences remain small and with a dense tomentose covering, and the pedicel does not develop, or does so to a lesser degree than that in pattern 6 .

Pattern 8 - (Mello-Silva 629, 635, 3189; figure 6B, C). Plants from Itacambira, intermediate between patterns 6 and 7. Mello-Silva 635 (figure 6C), collected among rocks, has a denser covering on the abaxial surface of its leaf blades than pattern 7 populations, coming close to pattern 6 . The individuals are of small habit, but the disposition of the leaf sheaths is similar to the plants of pattern 6 . The indumentum of the hypanthium is tomentose, as in the plants from pattern 7. Mello-Silva 629 and 3189 (figure 6B), collected in a sandy and rocky field, are composed of dwarfed individuals, with stems up to $6 \mathrm{~cm}$ in length. They are, in other vegetative aspects, identical to the individuals from pattern 6 . However, the apices of the emergences of the hypanthium are subulate and the leaves can be revolute.

Pattern 9 - (Mello-Silva 739, 3197; Rapini 764). Plants from Adão Colares, between Botumirim and Barrocão. The plants have an overall resemblance to that of pattern 6 , except that the subulate emergences of the hypanthium as well as of the fruits are densely tomentose, as in pattern 7 populations.

Pattern 10 - (Mello-Silva 462, 3221; figure 6D). Plants from Mato Verde, with leaves and hypanthium similar to those of pattern 7 , while the stem is intermediate between patterns 6 and 7. The pedicel does not develop in the majority of the fruits although in some individuals it do develop, but reaching only $1.5 \mathrm{~cm}$ in length.

Pattern 11 - (Mello-Silva 508, 662, 1452, 3191, 3193; Rivadavia Lopes 316, 338; figure 6E). Plants from Serra da Canastra, in Botumirim, and Itacambira. These populations most differ from the general norm for this species. The individuals are slender and much branched, the leaves are sparsely tomentose to glabrous on both surfaces and the hypanthium is densely covered with subulate emergences, similar to the populations of pattern 9 . The leaves are very fibrous, with fibre bundles composed of up to 10 layers of cells on the adaxial surface. The caps of the abaxial fibre-vascular bundles extend laterally to the epidermis of the furrows (figure 1C). Rivadavia Lopes 316 and Mello-Silva 3193 are somewhat intermediate between patterns 7 and 11 .

Pattern 12 - (Mello-Silva 461, 3218, 3220; Roque CFCR 14943; Taylor 1536; figure 6F). Plants from 


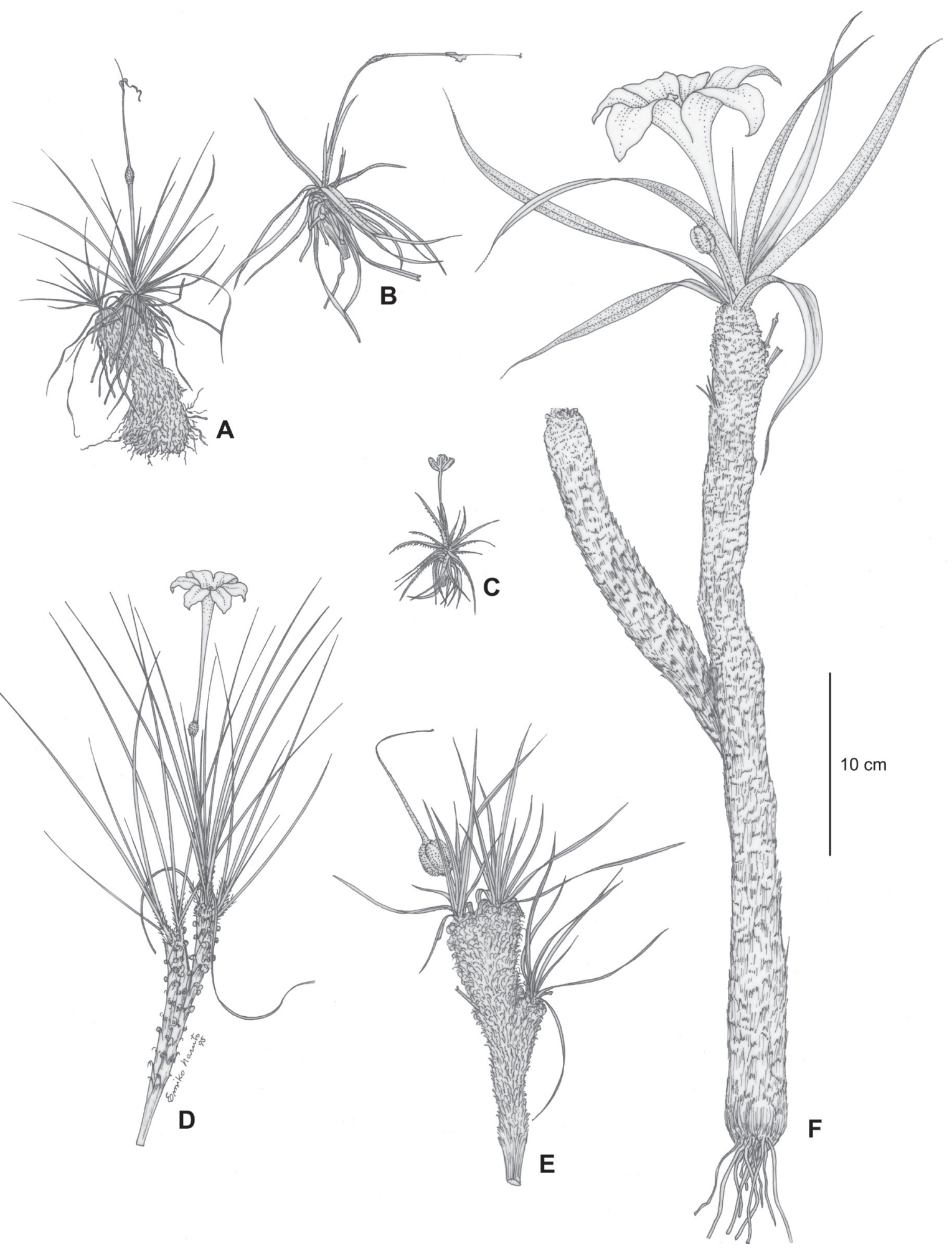

Figure 5. Patterns of V. hirsuta. A-C. Pattern 3. A. Mello-Silva CFCR8844. B-C. Mello-Silva 454. D. Pattern 4 (Mello-Silva CFCR11577). E. Pattern 5 (Menezes CFCR8817). F. Pattern 6 (Mello-Silva CFCR8976). 


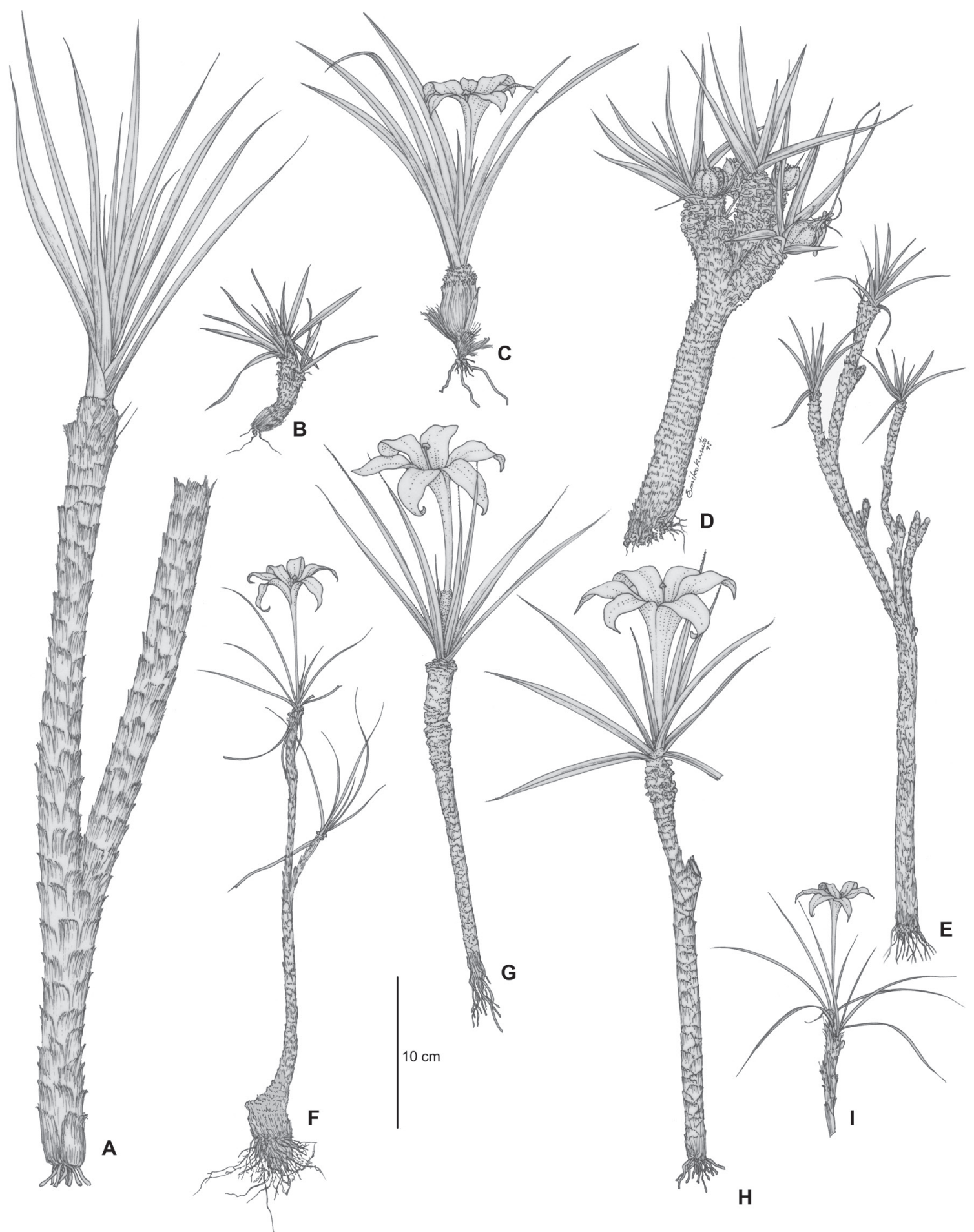

Figure 6. Patterns of V. hirsuta. A. Pattern 7 (Pirani 2261). B-C. Pattern 8 (B. Mello-Silva 629, C. Mello-Silva 635). D. Pattern 10 (MelloSilva 462). E. Pattern 11 (Mello-Silva 508). F. Pattern 12 (Roque CFCR14943). G-H. Pattern 13. G. Assis 332. H. Araújo 173. I. Pattern 14 (Souza CFCR15380). 
Caetité and Mato Verde. These plants are thinner and have narrower leaves than the plants within the pattern 11. The placement of the leaf sheaths put them closer to the pattern 7. As in the patterns 1 to 5 , the indumentum on the abaxial surface of the leaf is hirtellous; the adaxial side is glabrous. Additionally, some individuals from Mello-Silva 461 have well spread leaf sheaths and reflexed marcescent leaves, similar to those seen in plants of pattern 1. The hypanthial emergences are short and conical.

Pattern 13 - (Assis 332, Araújo 173, Hatschbach 78613; Mello-Silva 3205, 3206; figure 6G, H). Plants from Macaúbas, Cordeiros, Rio Pardo de Minas, and São João do Paraíso. Assis 332 and Araújo 173 should be placed near patterns 6 to 11, as judged by their habit and leaf posture. However, the foliar anatomy is similar to pattern 3. Araújo 173 and Hatschbach 78613 have flowers with hidden pedicels (figure $6 \mathrm{H}$ ), as seen in populations of pattern 6, while Assis 332, and Mello-Silva 3205 and 3206 have short, but visible pedicels (figure $6 \mathrm{G}$ ), as seen in populations of pattern 2.

Pattern 14 - (Souza CFCR15380, Wanderley 1378; figure 6I). Plants from Serra do Cabral. The flowers are apparently sessile, with subulate trichomes on the hypanthium, characteristics typical of the patterns 6 to 11 ; however, the posture and the indumentum of the leaves are typical of the patterns 1 to 5 . The stems of the plants from Wanderley 1378 are similar to those of pattern 2; on the other hand, the stems of the plants from Souza CFCR15380 (figure 6I) resemble those seen in the pattern 7, although they are much less robust. Both have foliar anatomical type 1 .

Vellozia tubiflora (A. Rich.) Kunth in Humboldt, Bonpland \& Kunth, Nov. gen. sp. 7: 155. $1825 \equiv$ Radia tubiflora A. Rich. in Kunth, Syn. pl. 1: 300. 1822. Type: VENEZUELA. AMAZONAS: ad Orinocum in rupibus graniticis, V-1800, F.W.H.A. Humboldt \& A.J.A. Bonpland s.n. (holotype $\mathrm{P}$ destroyed). Neotype, here designated. VENEZUELA. Amazonas: Puerto Ayacucho, behind (east) hotel Amazonas, 24-X1950, B. Maguire, R.S. Cowan \& J.J. Wurdack 29245 (NY 2 sheets, US duplicate) $\equiv$ Campderia tubiflora A. Rich., Bull. Soc. Philom. 79. 1822. Nom. illeg. $\equiv$ Barbacenia tubiflora (A.Rich.) B.D.Jacks., Index kew. 2(4): 1269. 1895.

= Barbacenia alexandrinae R.H. Schomb. in Hooker, Lond. J. Bot. 4: 13. 1845. Type: GUIANA. Roraima range of mountains, about $5^{\circ} \mathrm{N}$, elev. 3-4,000 ft., R.H. Schomburgk s.n. (lectotype, here designated, K) $\equiv$ Vellozia alexandrinae (R.H. Schomb.) Taub., Bot. Jahrb. 21: 424. 1896 三 Vellozia alexandrinae (R.H. Schomb.) Goethart \& Henrard in Henrard, Blumea 2: 363. 1937. Nom. illeg.

= Vellozia annulata Goethart \& Henrard in Henrard, Blumea 2: 365. 1937. Type: BRASIL. GoIÁs: Cachoeira da Vargem Grande (Serra da Baliza), entre les rochers, 4-I-1895, A.F.M. Glaziou 22212 (lectotype L, isolectotypes BR, $\mathrm{K}, \mathrm{P})$, syn. nov.

$=$ Vellozia cachimbensis L.B.Sm., Contr. U.S. Nat. Her. 35: 268, pl. 6.1962. Type. Brasil. PARÁ: Altamira, Serra do Cachimbo, elev. 425 m, 14XII-1956, J.M. Pires et al. 6232 (holotype IAN $n . v$, isotypes NY n.v., R), syn. nov.

= Vellozia cana Goethart \& Henrard in Henrard, Blumea 2: 367. 1937. Type: BRASIL. GoiÁs: Paranaúa, 12-II-1895, A.F.M. Glaziou 22219 (holotype L 2 sheets, isotypes $\mathrm{BR}, \mathrm{K}, \mathrm{MO}, \mathrm{P}$ ), syn. nov.

= Vellozia dawsonii L.B.Sm., Contr. U.S. Nat. Herb. 35: 270, pl. 7. 1962. Type: BRASIL. GoIÁs: 7 $\mathrm{km}$ south of Veadeiros, $14^{\circ} 30^{\prime} \mathrm{S} 47^{\circ} 30^{\prime} \mathrm{W}, 24-$ IV-1956, E.Y. Dawson 14580 (holotype US, isotype B fragment), syn. nov.

= Vellozia duidae Steyerm., Fieldiana Bot. 28(1): 157. 1951. Type: VENEZUELA. TerritóRIO Federal Amazonas: summit of cerro Duida, elev. 1025-1200 m, 2-IX-1944, J.A. Steyermark 58270 (holotype F).

$=$ Vellozia dumitiana R.E. Schult. in Schultes \& García-Barriga, Mutisia 12: 2. 1952. Type: COLÔMBIA. VAuPÉs: rio Kananarí (afluente del rio Apaporis), cerro Isibukuri, elev. ca. 700 m, 1-XII-1951, R.E. Schultes \& I. Cabrera 14726 (holotype GH n.v., isotype COL n.v.), syn. nov.

= Vellozia lanata Pohl, Pl. bras. icon. descr. 1(4): 130. 1828. Type: BRASIL. GoIÁs: Caldas Novas, VII-1820, J.B.E. Pohl s.n. (lectotype M), syn. nov.

= Vellozia lithophila R.E. Schult., Rev. Acad. Colomb. Cienc. 8(32): 459. 1952. Type: COLÔMBIA. VAuPÉs: Mesa La Lindosa, cerrito a $15-20 \mathrm{~km}$ al sur de San José del Guaviare, elev. 400-600 m, 13-15-XII-1950, J.M. Idrobo \& R.E. Schultes 632 (holotype GH 2 sheets, isotypes COL 2 sheets, US), syn. nov.

= Vellozia macarenensis Philipson in Schultes, 
Rev. Acad. Colomb. Cienc. 8(32): 461. 1952. Type: COLÔMBIA. Meta: Sierra de La Macarena, northern escarpment, on summit of knoll, elev. 900 m, 1-II-1950, W.R. Philipson et al. 2320 (holotype BM 2 sheets, isotypes COL 2 sheets, GH, S, US fragment), syn. nov.

= Vellozia machrisiana L.B. Sm., Contr. U.S. Nat. Herb. 35: 268, pl. 9, figs. 11, 12. 1962. Type: BRASIL. GoIÁs: region of the Chapada dos Veadeiros at $14^{\circ} 30^{\prime} \mathrm{S} 47^{\circ} 30^{\prime} \mathrm{W}, 14 \mathrm{~km}$ south of Veadeiros, 25-IV-1956, E.Y. Dawson 14674 (holotype US, isotype B), syn. nov.

= Vellozia macrosiphonia Taub., Bot. Jahrb. 21: 424. 1896. Type: BRASIL. GoIÁs: Serra dos Pirineus, Serra Dourada e Serra dos Veadeiros, E.H.G. Ule 3142 (holotype B? not found).

$=$ Vellozia maculata Goethart \& Henrard in Henrard, Blumea 2: 375. 1937. Type: BRASIL. GoIÁs: Serra da Baliza, Cachoeiras da Vargem Grande, 5-I-1895, A.F.M. Glaziou 22218a (holotype P, isotype K), syn. nov.

= Vellozia maudeana R.E. Schult., Bot. Mus. Leafl. Harvard 16(8): 198, pls. 29, 30. 1954. Type: COLÔMBIA. VAupés: río Karurú, tributary of río Vaupés, Mesa de Yambí, savannah Goo-ránhoo-da, $1^{\circ} 20^{\prime} \mathrm{N} 71^{\circ} 20^{\prime} \mathrm{W}$, elev. 950-1000 ft, 1516-IV-1953, R.E. Schultes \& I. Cabrera 19120 (holotype GH 4 sheets, isotypes A, B, BM, BR, COL, F, K, MO, P, S, U, US), syn. nov.

= Vellozia panamensis Standl., Journ. Washington Acad. Sci. 15: 457. 1925. Type: PANAMÁ. EASTERn ChIRIQuí: cerro Vaca, elev. 900-1136 m, 25-28-XII-1911, H.F. Pittier 5352 (holotype US, isotype F), syn. nov.

$=$ Vellozia phantasmagoria R.E. Schult., Bot. Mus. Leafl. Harvard 12(4): 130, pls. 19, 20. 1946. Type: COLÔMBIA. VAupÉs: upper Apaporis basin, Macaya river, mount Chiribiquete, elev. 1300-2100 m, 18-I-1944, R.E. Schultes 5741 (holotype GH, isotypes COL, MO n.v.), syn. nov.

= Vellozia rhynchocarpa Goethart \& Henrard in Henrard, Blumea 2: 378. 1937. Type: BRASIL. São PAUlo: inter Canna Verde et Cajuru ad Matto Grosso (fide Henrard 1937), II-1849, A.F. Regnell III.1241 (holotype S, isotypes L, US), syn. nov.

$=$ Vellozia uleana L.B. Sm., Contr. U.S. Nat. Herb. 35: 269, pl. 9, figs. 13, 14. 1962. Type: BRASIL. Roraima: Pacaraíma ("Depósito"), Surumu, auf Felsflächen der Serra de Mairary, elev. 1000-
1200 m, IX-1909, E.H.G. Ule 8372 (holotype MG 2 sheets, isotypes, B, K, L, S, US), syn. nov. $=$ Vellozia velutinosa Goethart \& Henrard in Henrard, Blumea 2: 382. 1937. Type: BRASIL. GoIÁs: Cabeceira do rio Sta Anna, 8-I-1895 (fide Henrard 1937), A.F.M. Glaziou 22218 (lectotype, here designated, K), syn. nov.

Figures 1B, D-F, H, J-L, 2, 7-10, 11B, C

Solitary, rarely caespitose, plants. Stem 2-200 cm long, $0.5-5 \mathrm{~cm}$ diam. at apex, entire to much-branched. Living leaves 4-17 in each branch, tristichous. Leaf sheaths adaxially glabrous, abaxially densely lanate or floccose or villose-tomentose to glabrescens or glabrous; apex recurved or straight, entire or lacerate. Leaf-lamina 6.5-65 cm long, 3-22 $\mathrm{mm}$ broad, linear-triangular, arcuate or plane, in sicco twisted and revolute, often straight or involute, green to cinereous-green, sometimes purplish when young, erect to erect-patent, deciduous, rarely some marcescent and reflexed, abaxial side densely to sparsely sericeo- to hirsute-lanate, trichomes of varying lengths, stellate-rotate, dendritic-spatulate or dendritic-filiforms, erect to adpressed, adaxial side mostly glabrous, sometimes with indumentum similar to that of the abaxial side, but less developed and sparsely distributed, rarely of the same appearance; lamina sometimes glabrous on both sides or ciliate on margins and midrib on abaxial side or ciliate only in the margins or lamina pubescent on both sides and glabrescens on the adaxial side; rarely viscous and/ or odoriferous; margins with indumentum similar to that of the lamina or ciliate; apex attenuate. Flowers 1-7(-15) per branch, odoriferous. Pedicel 4.5-24 cm long, 1-2 mm diam., trigonous, lightgreen, somewhat purplish towards the base and apex, sometimes completely purple to dark-purple, evident, smooth towards the base, bearing glandular emergences towards the apex. Hypanthium, in the ovary region, oblong-trigonous with attenuate angles, 5-15 $\mathrm{mm}$ long, 2-5 $\mathrm{mm}$ diam., green to greenish-purple, sometimes dark-purple, densely covered with glandular emergences, truncate or not, with 1-4 mm long. Hypanthial tube 2.3-10.5 cm long, 1-4 $\mathrm{mm}$ diam. at base and $2-5 \mathrm{~mm}$ diam. at apex, mostly white, sometimes green or greenish-purple or reddish or dark-purple at base, or totally purple, with glandular emergences sparsely distributed at the base and the region continuous to the external tepals, deciduous at fructification. Tepals $2.5-7.5 \mathrm{~cm}$ long, c. 1-2 cm broad, oblong-elliptical, mainly white, sometimes violet at base and midrib or totally violet 
to deep purple, outermost bearing small glandular emergences at base and midrib at abaxial side, adaxial side smooth; the innermost glabrous. Stamens 12-18, all equal, exserted from tube; filaments c. 2-15 mm long, white; anthers c. 1-2 cm long, yellow, latrorse; staminal appendages absent. Style 5-12.5 cm long, white, protruding beyond the stamens; stigma 2-7 mm diam., yellow. Capsule 1-2.3 cm long, 0.8-1.8 cm diam., oblong-ellipsoid to oboval-oblong, trigonous, loculicidal, green or greenish-purple when immature, chestnut brown at maturity, at first covered by the hypanthium, this later caducous. Seeds numerous, c. 1.5-2 mm long, verrucose or foveate, dark-brown to blackish, exotesta without spiral thickenings.

Foliar and pedicellar anatomy (figures 1B, D-F, H, J, 10) - Lamina dorsiventral. Furrows ca. 1/2 of the thickness of the lamina, rarely less deep to inconspicuous, smooth or with more or less conical, small papillae, not very conspicuous. Cuticle thicker on the adaxial surface. Adaxial epidermis (uni-) pluriseriate, abaxial 1-2-seriate. Stomata mainly inside the furrows or on their region in abaxial surface when the furrows are inconspicuous, few on the adaxial surface. Aquiferous hypodermis on the adaxial surface 1(-2)-seriate, extending adaxially, as aquiferous parenchyma, to endodermis and to furrows or to the spongy parenchyma on the region of the furrows when these are inconspicuous. Palisade parenchyma 2-5-cell layer thick, rarely absent (Idobro 632), abaxially merging with spongy parenchyma. Fibro-vascular bundles surrounded by endodermis as leaf bundle sheath. 1-2(-3) larger vessels present in each bundle. Phloem strands 2, U-shaped beneath the xylem, protophloems separated by fibres or parenchymatic cells. Pericyclic fibres extending adaxially to the aquiferous parenchyma and abaxially to (or almost to) the epidermis. Fibres strands 1-6 cell layer thick present on adaxial surface or absent and, on abaxial surface, 1(-2-3) cell layer thick present on all surface or near furrows edges or, rarely, absent. Pedicel triangular in transverse section. Fibrovascular bundles 6 . Belt of sclerified cells present. Specimens examined: PANAMA. ChIRIQuí: cerro Vaca, Pittier 5352 (F, US); Veraguas: La Yeguada, cerro Altos de La Gallota, Correa A. 1911 (MO, PMA n.v.); COLOMBIA. GuAINÍA: vicinity of cerro Monachi, Schultes 10067 (GH); VICHADA: Maipures, Orinoco river, Chaffanjon 326 (P); Spruce 3606 (K, P); Thomas 2556 (NY); Raudal San Borja-Ventanas, Pinto E. 1264 (COL, P); $1 \mathrm{~km}$ de Casuarito, Pinto E. 1396 (COL n.v., P); El Tuparro, Daniel 138 (COL);
Vincelli 1263 (COL); Meta: Sierra de La Macarena, Acosta 8a (COL); Acosta s.n. (COL 81406); Callejas 6912 (GH, HUA n.v., K); García-Barriga 17032 (COL, US); Idrobo 1306 (COL 2 sheets, NY, US), 5554 (COL); Jaramillo M. 2112 (COL); Philipson 2320 (BM 2 sheets, COL 2 sheets, GH, S); Starr 90 (COL); Thomas 1596 (COL 2 sheets, P); V AupÉs: San José del Guaviare, Cuatrecasas 7700 (F, COL); Mesa La Lindosa, Idrobo 632 (COL 2 sheets, GH 2 sheets, US); Schultes 22602 (COL); río Karurú (Carurú), Mesa de Yambí, Schultes 19120 (A, B, BM, BR, COL, F, GH 4 sheets, K, MO, P, S, U, US); mount Chiribiquete, Schultes 5741 (COL, GH); Mitú, río Kubiyú (Cubigú), cerro Kañendá, Schultes 18317 (GH), 24283 (COL, GH 2 sheets); Zarucchi 1182 (COL 2 sheets, GH, K, US); río Paraná-Pichuna, Schultes 19945 (GH, U, US); Zarucchi 1317 (COL 2 sheets, GH); cerro Yapobodá, Allen 3237 (COL 2 sheets, MO, US), 3273 (COL); Schultes 20019 (GH, US); García-Barriga 15832 (COL, F); Schultes 22602 (GH); río Kubiyú (Cubigú), sabana de Guranjudá, García-Barriga 16050 (COL); Soejarto 2412 (COL, F, K); río Kananarí (Cananari), cerro Isibukuri, Schultes 13350, paratypus of $V$. dumitiana (COL, GH 3 sheets, U); García-Barriga 13804, paratypus of $V$. dumitiana (COL); Schultes 13410, paratypus of $V$. dumitiana (GH 2 sheets, $\mathrm{U}$ ); $0^{\circ} 51^{\prime} \mathrm{N}$ $70^{\circ} 35^{\prime} \mathrm{W}$, Schultes 15050a (GH, US); Caquetá: San Vicente del Caguán, sitio "La Danta", Betancur 1926 (COL n.v., SPF). VENEZUELA. Bolivar: Cedeño, road to Caicara del Orinoco, Steyermark 131830 (MO); cerro Calentura, Jangoux 10110 (MO, VEN n.v.); serranía Guanay, Huber 11054 (MYF n.v., NY, U); Sabana de Arekuna, río Caroni, Prance 28346 (NY); Laja del Zamuro, río Parguaza, Trujillo 10780 (MBM, MY n.v.); río Paraguaelev, Stergios 10541 (NY), 10081 (MO, PORT n.v.); El Dorado, Steyermark 105474 (NY, VEN n.v.); río Carrao, alto Caroní, Puig 2861 (US); Agua Amena, Steyermark 131408 (MO); río Parguaza, Cerros de los Gavilanes, Croizat 56 (F); Luepa, Uarama Tepuí, Steyermark 54 (K, NY, P, VEN n.v.); Steyermark 554 (NY, VEN n.v.); Auyan Tepuí, Tate 1196 (NY, US); Steyermark 93208 (B, BR, F, GH, K, MO, NY, P, S, U); Delascio 13208 (MO, VEN n.v.); cerro Guaiquinima, Steyermark 113155 (NY, VEN n.v.); cerro Guaiquinima, Steyermark 113210 (F, K, VEN n.v.), 117231 (F, MO, VEN n.v.), 117413 (MO, VEN n.v.); río Karuai, Ptari Tepuí, Steyermark 60326 (F 2 sheets, MO, NY, S); Kavanayén (Cavanayen), Lasser 1774 (F, NY, VEN n.v.), 1777 (F, K, NY, US, VEN n.v.); Piar, $5 \mathrm{~km}$ al S 
de Kavanayén, Huber 10580 (K, NY n.v., MYF n.v.); Ilu Tepuí, Maguire 33532A (NY); "El Abismo", Liesner 19885 (MO, VEN n.v.); APURE: Pedro Camejo, Davidse 14582 (MO n.v., MEXU); Amazonas: cerro Ualipano, Cardona 2937 (MO, VEN n.v.); Atures, Savane d'Atures, Gaillard 100 (P); rio Orinoco, raudal de Atures, Pinto E. 1370 (COL n.v., P); $30 \mathrm{~km} \mathrm{~N}$ of Puerto Ayacucho, Gentry 14716 (MO, US); Caño Galipero, Colella 1237 (NY); 5-6 km al norte de Puerto Ayacucho, Guanchez 1774 (MO); $3.5 \mathrm{~km} \mathrm{~N}$ de Puerto Ayacucho, Romero 1676 (GH); Puerto Ayacucho, Gentry 14454 (MO); Foldats 3526 (NY, VEN n.v.); Kral 71713 (MO, NY, VDB n.v.); Liesner 17243 (MO, U); Maas 5152 (U); Maguire 29245 (NY 2 sheets, US), 36051 (F, NY); Phelps 82 (NY); Thomas 2573 (MICH n.v., NY); Williams 12974 (F 2 sheets, K), 15880 (F 2 sheets); Parque Sucre, Steyermark 131596 (MO n.v., NY); Puerto Ayacucho-Sanariapo, Bunting 3465 (U); laja de Carestía, bajo Sanariapo (Samariapo), Williams 16022 (F, GH, NY, RB, US 2 sheets); vicinity of Sanariapo (Samariapo), río Sanariapo, Steyermark 58450 (F 2 sheets, NY); cerro Guanay, Maguire 30177 (NY), 31679 (NY 2 sheets); cerro Moriche, Maguire 30835 (F, NY), 30941 (F, NY, S), 30955 (NY), 31003 (NY 3 sheets); cerro Yutaje, Maguire 35131 (F, NY), 35136 (NY), 35248 (F, NY 2 sheets, $\mathrm{S}$, US); río Coro-Coro, Yutaje, Steyermark 117049 (MO, VEN n.v.); Liesner 10960 (MO, NY, VEN n.v.); cerro Yapacana, Maguire 30703 (NY 2 sheets); Steyermark 103171 (P, VEN n.v.); Atabapo, near Culebra, Liesner 17518 (MO n.v., NY); entre el cerro Duida y Huachamacari, Steyermark 125834 (MO, NY, VEN n.v.); mount Duida, Maguire 29119 (NY), 29156 (F, NY); Steyermark 58270 (F), 126415 (MO, NY, VEN n.v.); Tate 801 (NY; foto K, NY); Rio Negro, cerro Vinilla, Steyermark 130411 (MO, U, VEN n.v.); Croizat 457 (F); GUYANA. Roraima mountains, Schomburgk s.n. (K); Roraima, Schomburgk 815 (P), 984 (BM), 1569 (B not found, G n.v., LE n.v.; photos F, GH, M, NY); Schomburgk s.n. (P); Upper Mazaruní district, Kuyayuwen, Boyan 7 (K, NY, U); Imbaimadai(?) savanna, Graham 105 $(\mathrm{K})$; Upper Mazaruní river, Merume mountains, Maguire 43855 (NY 2 sheets), 45918 (NY); Mazaruní-Potaro region, Pakaraima (Pacaraima) mountains, Pipoly 7783 (BRG n.v., NY, US n.v.); Maguire 32307 (NY, US); Cuyuni-Mazaruni, Pakaraima Mts, Hoffman 1980 (K, U, US n.v.); Chinoweng, Wandabu mountains, Boyan 22 (K, NY). BRAZIL. Roraima: Pacaraíma ("Depósito"), Ule
8372 (B, L, MG, S, US); PARÁ: Alto Tapajós, rio Cururu, Kereputiá, Egler 1237 (MG, NY); Alto Tapajós, rio Cururu, Erereri, Egler 1277 (MG); Altamira, Serra do Cachimbo, Pires 6111 (IAN n.v., NY, R, US), 6232 (IAN n.v., NY n.v., R; photo, B, US), 6235 (IAN n.v., NY, R; photo, NY, US); Amazonas: Barcelos, Serra Aracá, Pires 15053 (IAN n.v., MG); Prance 29160 (INPA, NY); rio Demini, Miranda s.n. (SPF 79757); Miranda s.n. (SPF 79758). Ceará: Viçosa do Ceará, Andrade-Lima s.n. (SPF 34307); Fernandes s.n. (EAC n.v., SPF 64749); Rio Grande do Norte: entre Santo Antônio e São Gonçalo do Amarante, Andrade-Lima 77-8325 (IPA); Piauí: Piripiri, Barroso 272 (RB); Menezes 1007 (SPF); Pires 17348 (MG); Tocantins: Araguaína, Carauta 1866 (RB 2 seets); Presidente Kennedy, Plowman 8291 (F, INPA n.v., MG n.v., NY); Guaraí, Hatschbach 38505 (MBM, US n.v.); BAHIA: Piatã, Mello-Silva CFCR7386 (K 3 sheets, SPF); Abaíra, Ganev 623 (HUEFS n.v., K, SPF); Pirani H51357 (CEPEC n.v., HUEFS n.v., K, SPF); Sano H52147 (CEPEC n.v., HUEFS $n$. v., K, SPF); MATo Grosso: Guarantã do Norte, Serra do Cachimbo, Nascimento 540 (MG); fazenda Cachimbo, Cordeiro 1191 (MG n.v., NY, US); rio Juruena, cachoeira Misericórdia, Rosa 1994 (F, MG, MO 2 sheets, NY, RB 2 sheets); rio Juruena, cachoeira Taquari, Rosa 2018 (MG, NY, US); GoIÁs: Cavalcante, Hatschbach 36869 (MBM, MO, P); Ratter 4525a (UB); Splet 277 (SPF, UB); Colinas do Sul, Arbo 3667 (CTES n.v., HRCB n.v., K, SPF); Cavalcanti 405 (CEN, SPF, US); Hatschbach 56313 (MBM n.v., SPF); Mello-Silva 551 (CEN, K, SPF); Walter 3649 (CEN n.v., SPF); Teresina de Goiás, Hatschbach 58358 (MBM n.v., RB 2 sheets, SPF), 60310 (BR, MBM, SPF); Minaçu, Mello-Silva 548 (CEN, SPF); Pereira 1547 (IBGE n.v., SPF, US); Alto Paraíso de Goiás, Anderson 6380 (F, K, MO, NY, RB, UB, US); Arbo 3570 (CTES n.v., HRCB n.v., K, U); Barroso s.n. (RB 141476, 2 sheets); Cavalcanti 675 (CEN n.v., SPF), 1368 (CEN, K, SPF); Dawson 14580 (B fragment, US), 14674 (B, US); Duarte 10794 (RFA); Glaziou 22212 (K, L, P), 22217 (BR, K, L, P), $22218 a$ (P); Graff 184 (R); Graziela (Barroso) 594 (UB); Harley 11417 (K, SPF), 11464 (K, UB); Hatschbach 36314 (MBM, NY, US n.v.), 36322 (MBM, SP, US n.v.), 36801 (MBM, MO, US), 36908 (MBM, US n.v.), 53929 (MBM n.v., SPF), 60298 (MBM n.v., MEXU, SPF), 60303 (MBM, SPF); Irwin 12454 (GH, MO, NY, S, SP, UB, US), 12556 (F, IAN n.v., K, MO, NY, S, UB, US n.v.), 12622 (MO, NY, S, SP, UB, US), 12648 
(NY, UB, US), 12697 (NY), 24344 (IAN n.v., NY n.v., UB, US), 32188 (IAN n.v., NY n.v., SPF, UB n.v.), 32227 (F, IAN n.v., NY n.v., SP, UB, US n.v.); King 8890 (K, M, MO, UB, US); Martinelli 3789 (RB, SPF); Mello-Silva 553 (CEN, SPF), 554 (CEN, SPF); Mendonça 2628 (IBGE, SPF); Menezes 273 (SPF), 274 (SPF, US n.v.), 598 (SPF), 599 (K, SPF), 600 (K, SPF); Menezes s.n. (SPF 71864); Silva 53 (RB, SPF); Oliveira 500 (MBM, SPF, US); Pereira 1518 (IBGE n.v., SP, SPF, US); Pereira Neto 111 (IBGE); Pirani 1683 (K, SPF), 1734 (K 2 sheets, SPF), 1824 (K 2 sheets, SPF), 1871 (K 2 sheets, $\mathrm{SPF}$ ); Prance 58275 (NY n.v., UB, US), 58276 (NY n.v., UB); Ratter 7317 (E n.v., K); Rivadavia Lopes 181 (SPF); Rizzo 8128 (SPF, UFG n.v.); Romaniuc Neto 635 (SP, SPF); Toledo 283 (CEPEC, SP, SPF), 284 (CEPEC, SP, SPF); Ule 790 (R); Wanderley 1832 \& Kral 75865 (SP, VDB n.v.); estrada Alto Paraíso Campos Belos, Shepherd 3724 (MBM, UEC); Hatschbach 60296 (MBM n.v., MEXU, SPF); Cavalcanti 1327 (CEN, SPF), 1342 (CEN, K, SPF); Alto Paraíso de Goiás - Teresina de Goiás, Cavalcanti 380 (CEN, K, SPF, US); São João da Aliança, Azevedo 501 (IBGE, SP, US n.v.); Paranaúa (Paranã?), Glaziou 22219 (L 2 sheets, BR, K, MO, P); Formosa, Hatschbach 39365 (B, MBM, US, W); Pirenópolis, Irnaldo s.n. (UB n.v., US 2568805); Meira Neto 20007 (UEC); Menezes 1004 (K, SPF); Morellato 19936 (UEC); Semir 20455 (UEC), 20530 (UEC), 20642 (UEC); Siqueira 2345 (FCAB); Ule 372 (P, R); Goiás, Andrade-Lima 66-4405 (IPA); Cavalcanti 460 (CEN, US n.v.); Duarte 10247 (RFA); Eunice s.n. (NY, UB 48039, US 2 sheets); Heringer 10844 (UB), 10925 (UB); Irwin 11734 (IAN n.v., K, NY, S, SP, UB, US); Magnago 99 (RB); Rizzo 4657 (RB); Thomas 5767 (NY n.v., K, SPF); Mossâmedes, Kirkbride Jr. 3318 (US); Anápolis, Magalhães 8627 (NY, UB); Cristalina, Arbo 3319 (CTES n.v., HRCB, SPF); Hatschbach 36392 (MBM, MO, NY, US n.v.), 51809 (BR, MBM, SPF); Heringer 9606 (HB n.v., NY, UB), 11320 (UB, US), 17586 (IBGE, K, MG); Mello-Silva 556 (K, SPF); Menezes 776 (SPF); Oliveira s.n. (HUFU 2878 n.v., SPF); Pirani 1615 (K n.v., SPF); Arenópolis, Anderson 12421 (MBM, MICH n.v., SPF); Ipameri, Cordovil-Silva 493 (CEN, SPF); Caldas Novas, Pohl s.n. (M); Minas Gerais: São Sebastião (?),Weddell 1901 (P); Patrocínio, Irwin 25614 (IAN n.v., NY n.v., SPF, UB, US); São Roque de Minas, Romero 1655 (HUFU n.v., SPF), 1710 (HUFU n.v., SPF), 1937 (HUFU n.v., SPF); Distrito Federal: Brasília, Heringer 1293/9099 (HB n.v.,
SP); Pereira 21 (IBGE n.v., K, SPF), 21-A (IBGE, UEC); Gama, Heringer 1293/9099 (sic) (UB), 10966 (UB), 11215 (SPF), 11785 (UB); Irwin 19468 (F, IAN n.v., K, MO, NY, S, UB); Maia s.n. (SP 111606); Pires 9895 (UB, US); Smith 15070 (NY, P); Sobradinho, Fontella Pereira 3284 (R); São PAUlo: Inter Canna Verde et Cajuru ad Matto Grosso, Regnell III.1241 (L, S, US); Serrana, Sazima 20707 (UEC); Altinópolis, Marcondes-Ferreira 498 (SPFR), 516 (SPFR); Mello-Silva 2158 (BHCB, HRCB, HUFU, $\mathrm{K}, \mathrm{MBM}, \mathrm{NY}$, SP, SPF, SPFR, UEC); Morro do Forno, Mello-Silva 2185 (RB, SPF); Oliveira s.n. (SPF, SPFR 8605). BOLIVIA. SANTA CRUZ: Velasco, Concepción - San Ignacio, Ibisch 93845 (BONN n.v., SPF); Cerro Pelao, Guillén 1101 (MO n.v., USZ n.v., SPF); Quevedo 1110 (K, MO n.v., USZ n.v., SPF); Without precise location: central Brazil, Rizzo 7243 (SPF, UFG); Weddell 2570 (P).

Vellozia tubiflora is the most widely distributed species within the Velloziaceae. Its area of occurrence stretches from Panama, at $9^{\circ} \mathrm{N}$, until the State of São Paulo, in Brazil, at $21^{\circ} 30^{\prime}$ S. Its most eastern occurrence is in the mountains that separate the states of Ceará and Piauí, in Brazil, at $41^{\circ} \mathrm{W}$, and its most western extension is the eastern flank of the Colombian Andes, in San Vicente del Caguán, at $75^{\circ} 10^{\prime} \mathrm{W}$. It occurs from altitudes of $50 \mathrm{~m}$, at the edge of the Orinoco river, to above $2,000 \mathrm{~m}$, in the mountains at the border between Brazil and Venezuela. It can be found growing on granitic-gneissic or quartzitic outcrops, which are bare or, at best, sparsely vegetated, although a majority of the populations inhabit sites nearer to water courses or which are constantly humid. The largest concentrations of this species are found in the mountains of Goiás State, Brazil, and the high plains of the Guyanas. South of the equator, $V$. tubiflora occupies a vast area on the ancient Brazilian Shield. Major concentrations of this species occur in the mountains in Goiás and in the Distrito Federal. From there, to the south, the species penetrates the mountains of western Minas Gerais, reaching the region around Serrana and Cajuru, in north-central São Paulo State. Disjunct populations are found around Catolés and Piatã in the Chapada Diamantina mountains in Bahia (being their only locality of occurrence in the Espinhaço range), in the mountains which separate the states of Ceará and Piauí, in the Serra do Estrondo, in Tocantins, in the Serra do Cachimbo and the waterfalls of the Juruena and Cururu rivers, both along the border between the states of Mato Grosso and Pará, as well as in Bolivia, 
in the lower elevations in the Paraguá river basin. North of the equator, the area of distribution of $V$. tubiflora extends over the entire region of the Roraima formation, including the sedimentary mountains of Guyana and the "gran sabana" of Venezuela, the peaks along the frontier with Brazil and, to the west, the Negro and Guainía rivers, in Colombia, in a series of terraces reaching up to the Macarena Range along the flanks of the Andes. It also occurs in the Orinoco, Casiquiare, Negro and Guainía rivers basins, areas that were most likely contiguous before the up lifting of the high plains (Maguire 1970). The presence of this plant along river margins results in considerable differences in altitude among different Venezuelan populations, which are otherwise located very close to one another. Approximately $150 \mathrm{~km}$ separates two populations along the margin of the Orinoco river; one grows at $60 \mathrm{~m}$ of altitude, and the other population at $1800 \mathrm{~m}$, at cerro Guanay. Less than $30 \mathrm{~km}$ separates a population along the Cunucunuma river, at $180 \mathrm{~m}$, from another at cerro Duida, at 2,400 $\mathrm{m}$ above sea level. In Panama, $V$. tubiflora occurs on the eastern flanks of the cerro Chiriqui, where the vegetation is similar to that seen in the high mountains in Colombia (Simpson \& Neff 1985). Isolated populations growing on rock outcrops also exist in numerous spots within the Amazon basin. Within the Espinhaço range in Brazil, where the large majority of species of Velloziaceae are found, V. tubiflora only occurs in Bahia State, in the mountains to the northeast of the Paramirim river and to the north of the São Paulo river, an affluent of the Brumado river (figure 2). The isolated populations of $V$. tubiflora exhibit morphological and anatomical divergences, principally in terms of their habit and leaf covering. Maguire (1969: 35) and Ayensu (1974: 70-71) have already noted those divergences. However, the characteristics that define the species remain constant. Throughout the area of distribution of $V$. tubiflora, eight patterns can be roughly defined: Pattern 1 - (Acosta COL 81406, 8a; Allen 3237; Andrade-Lima SPF 34307; Barroso 272; Betancur 1926; Callejas 6912; Carauta 1866; Cardona 2937; Colella 1237; Correa 1911; Croizat 56; Cuatrecasas 7700; Delascio 13208; Egler 1237, 1277; Fernandes SPF 64749; Foldats 3526; García-Barriga 15832, 16050, 17032; Gentry 14454, 14716, Guanchez 1774; Guillén 1101; Huber 11054; Ibisch 93845; Idrobo 632; Jangoux 10110; Kral 71713; Lasser 1774, 1777; Liesner 10960, 17243, 17518, 19885; Maguire 29119, 29156 [F], 29245, 30177, 30703,
30835, 30941, 30955, 31003, 31679 [NY sheet 1], 33532a, 35131, 35136, 35248, 36051; Mello-Silva 2158, 2185; Phelps 82; Pinto 1264; Pittier 5352; Puig 2861; Prance 28346; Quevedo 1110; Regnell III.1241; Romero 1676; Sazima 20707; Schomburgk s.n. [K], 815, 984, 1569; Schultes 5741, 18317, 19945, 20019, 22602, 24283; Soerjato 2412; Spruce 3606; Stergios 10081, 10541; Steyermark 54, 554, 58270, 58450, 93208, 60326, 105474, 113155, 113210 [F], 117049 , 117413, 126415, 131596, 130411, 131408, 131830; Tate 801, 1196; Thomas 1596, 2556, 2573; Vincelli 1263; Williams 12974, 15880, 16022; Zarucchi 1182, 1317; figure 7A). Includes the types of $V$. alexandrinae, $V$. duidae, V. lithophila, V. panamensis, $V$. phantasmagoria, V. rhynchocarpa, and V. tubiflora. The plants demonstrate a great variation in the width of the stems apices and leaves, varying between 0.5 $5 \mathrm{~cm}$ and $0.4-2 \mathrm{~cm}$, respectively. The leaf sheaths are in general densely lanate to their apices, or glabrate. The leaf blades are glabrous on the adaxial side, sometimes tomentose and glabrate and appressedtomentose on the abaxial side, or glabrate, rarely erect-tomentose on both faces (Maguire 35131). Sometimes the base of the leaf blade is shortly ciliate (e.g. Maguire 35241). They occur in Venezuela, in the states of Bolivar and Amazonas, up to the border with Brazil, in Vichada, Meta, Vaupés and Caquetá in Colombia, and in Santa Cruz in Bolivia, at altitudes that vary between 80 and 2100 meters. There are disjunct populations in Brazil, along the Caruru river, in Pará, and in Goiás. Individuals from Zarucchi 1317, of Vaupés, and Maguire 29156 and Steyermark 58270, from cerro Duida in Venezuela, have glabrate leaves, similar to those of pattern 6 . Some collections (e.g. Carauta 1866, from Goiás, Brazil, Steyermark 131408, from Bolivar, and Colella 1237, from Amazonas, Venezuela) have stems with well-spaced sheaths, as occurs also in populations of the pattern 5. Collections from São Paulo, Brazil ( $V$. rhynchocarpa, e.g. Sazima 20707, Regnell III.1241), from Ceará (Andrade-Lima s.n., Fernandes s.n.) and Piauí (Barroso 272) are intermediate with pattern 4. Maguire 35248 has the largest number of flowers in a single inflorescence ever found in Velloziaceae (12-15), surpassing Barbacenia polyantha Goethart \& Henrard, which has up to 12 flowers (Henrard 1937). Idrobo 632 (type specimen of $V$. lithophila) shows a somewhat different foliar anatomy. It has not a conspicuous palisade parenchyma (figure 1E), although its overall anatomical appearance is similar to that of the types of $V$. macarenensis, $V$. dumitiana 
and $V$. duidae.

Pattern 2 - (Dawson 14674; Glaziou 22218a; Hatschbach 36322, 53929, 60303; Irwin 12454, 12697, 32227; King 8890; Maguire 32307; Martinelli 3789; Menezes 598; Pirani 1683; Rivadavia Lopes 181; Rosa 1994; Toledo 283; Tillet 43855; figure 7B, C). Includes the type material of $V$. machrisiana and $V$. maculata. They have an erect stem from 7 to 10 $\mathrm{mm}$ in diameter, rarely $20 \mathrm{~mm}$, and the leaf sheaths at the apex of the stem are revolute. The plants are almost glabrous; the trichomes are very short, occurring only on the abaxial side of the sheaths as well as on the margins and on the abaxial surface of the central vein of the leaves. Occasionally, the leaves are glabrous. The leaf blades are slightly arched, almost flat, very similar to, or equal to, the transversal posture of the leaf blade found among members of pattern 8 . These plants almost always grow along the banks of rivers or of lesser creeks in the region around Chapada dos Veadeiros, Goiás (e.g. Dawson 14674, Irwin 12454, Pirani 1683) and the Cachoeira da Misericórdia along the Juruena river in Mato Grosso (Rosa 1994), both in Brazil, as well as at Pakaraima mountains (Maguire 32307) and the Mazaruni river (Tillet 43855) in British Guyana. The plants from Rivadavia Lopes 181, from Chapada dos Veadeiros, are very similar to plants of pattern 3.

Pattern 3 - (Arbo 3667; Hatschbach 56313; MelloSilva 551; figure 7D). Plants growing along the edges of the Tocantinzinho river, in Colinas do Sul, Goiás, Brazil. These are similar to that of pattern 2, except that the plants are caespitose and quite a bit smaller, with stems $5 \mathrm{~cm}$ tall, at most.

Pattern 4 - (Anderson 12421; Graham 105; Hatschbach 39365, 60310; Heringer 1293/9099; Idrobo 1306; Magalhães 8637; Maguire 31679 [NY, sheet 2]; Mello-Silva 548; Menezes 1007; Miranda SPF 79757, 79758; Pereira 1547; Pires 9895, 17348; Philipson 2320; Prance 29160; Rosa 2018; Steyermark 113210 [K]; Trujillo 10780; Ule 8372; figure 7E-G). Includes the type collections of $V$. macarenensis and $V$. uleana. These are exactly the same as the plants of pattern 2, except for the leaf indumentum. The leaves have long or short appressed trichomes, which may vary in density. The collections from Cachoeira Formosa along the Juruena river in Mato Grosso, Brazil (Rosa 2018), and from Serra da Mesa in Minaçu (Mello-Silva 548) and Caiapônia (Anderson 12421), both in Goiás, Brazil, all possess very long and dense, sometimes extremely hirsute, trichomes. The collections from Serra do Aracá
(Prance 29160), from the Demini river in Amazonas State, Brazil (Miranda s.n.), and from cerro Guanay, Venezuela (Maguire 31679) have a short and dense indumentum, although in some collections from northern Brazil and Guyana (Ule 8372, Graham 105) as well as from Piauí State, Brazil (Menezes 1007, Pires 17348) the indumentum is sparse. Some are intermediate between this pattern and the pattern 2: they have leaves with very short, almost nonexistent, trichomes (e.g. Magalhães 8627, from Anápolis, Goiás, Brazil, and Trujillo 10780, from the Parguaza river in the State of Bolívar, Venezuela). Menezes 1007 , because of its robust stem, resembles plants of pattern 8. Steyermark 113210, from K, fit within this pattern, while those from $\mathrm{F}$ resemble pattern 1 . The same is true for Maguire 31679 (sheets 1 and 2, respectively). Philipson 2320 (type collection of $V$. macarenensis) belongs to this pattern, although it is more robust and, not considering the indumentum, it is very much the same as the plants from the type collection of $V$. dumitiana, within pattern 6 . Hatschbach 60310, in light of the delicate stem, resembles the plants of pattern 3 . The palisade parenchyma is inconspicuous in Rosa 2018 (figure 1D), as in some collections of patterns 1 and 8 .

Pattern 5 - (Barroso 594; Cavalcanti 460, 675, 1368; Cordeiro 1191; Duarte 10247; Eunice UB 48039; Ganev 623; Glaziou 22219; Harley 11464; Hatschbach 38515; Heringer 10844, 10925, 10960 , 11215, 11785; Irnaldo US 2568805; Irwin 11734, 12556, 19468, 25614; Kirkbride 3318; Maia SP 111606; Mello-Silva 553, CFCR7386; Nascimento 540; Pereira 21, 21a; Pereira Neto 111; Pirani H51357; Pires 9895; Plowman 8291; Pohl s.n. [M]; Sano H52147; Shepherd 3724; Smith 15070; Thomas 5767; Toledo 284; Wanderley 1832 \& Kral 75865; figure $8 \mathrm{~A}, \mathrm{~B})$. Plants corresponding to the types of $V$. cana and $V$. lanata. They are characterized by a dense, long hirsute to woolly indumentum, principally on the abaxial side of the leaf. On the adaxial side, the indumentum is always more sparse, or almost glabrous (e.g. Heringer 11785, Irwin 25614) or glabrous (e.g. Heringer 11215, Cavalcanti 1368). In some collections (Cavalcanti 1368, MelloSilva CFCR7386), the dry leaves will remain flat or involute, in contrast to the general state of the species, which show the dry leaves normally as revolute. The leaf sheaths are also woolly and imbricate. The stem is generally between 2 and $3 \mathrm{~cm}$ thick, varying in length from 8 to $120 \mathrm{~cm}$. Populations of this pattern are found in Brazil in Serra Dourada, Goiás, in the 


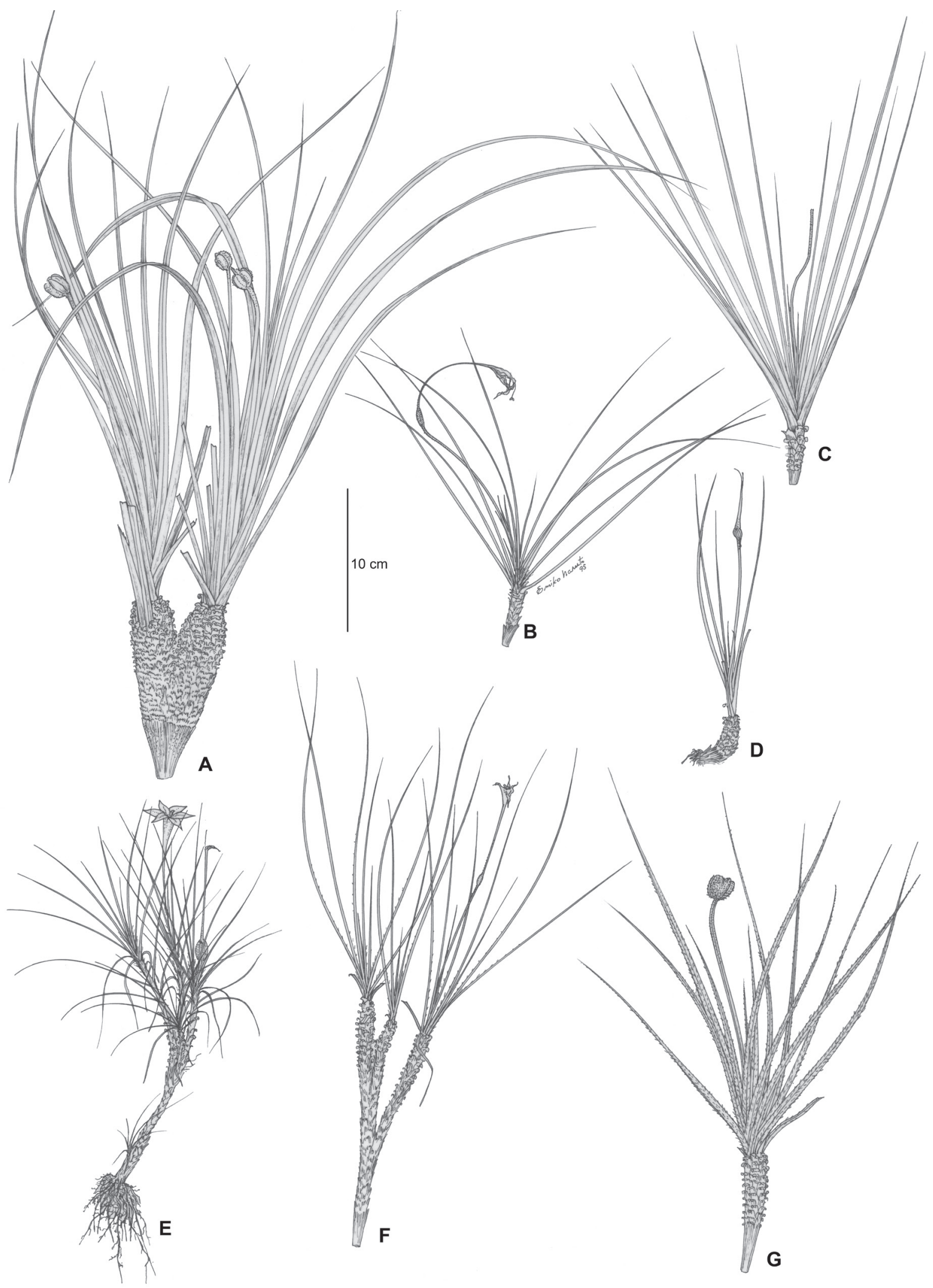

Figure 7. Patterns of V. tubiflora. A. Pattern 1 (Maguire 31003). B-C. Pattern 2. B. Rivadavia Lopes 181. C. Glaziou 22218a. D. Pattern 3 (Mello-Silva 551). E-G. Pattern 4. E. Hatschbach 60310. F. Ule 8372. G. Rosa 2018. 


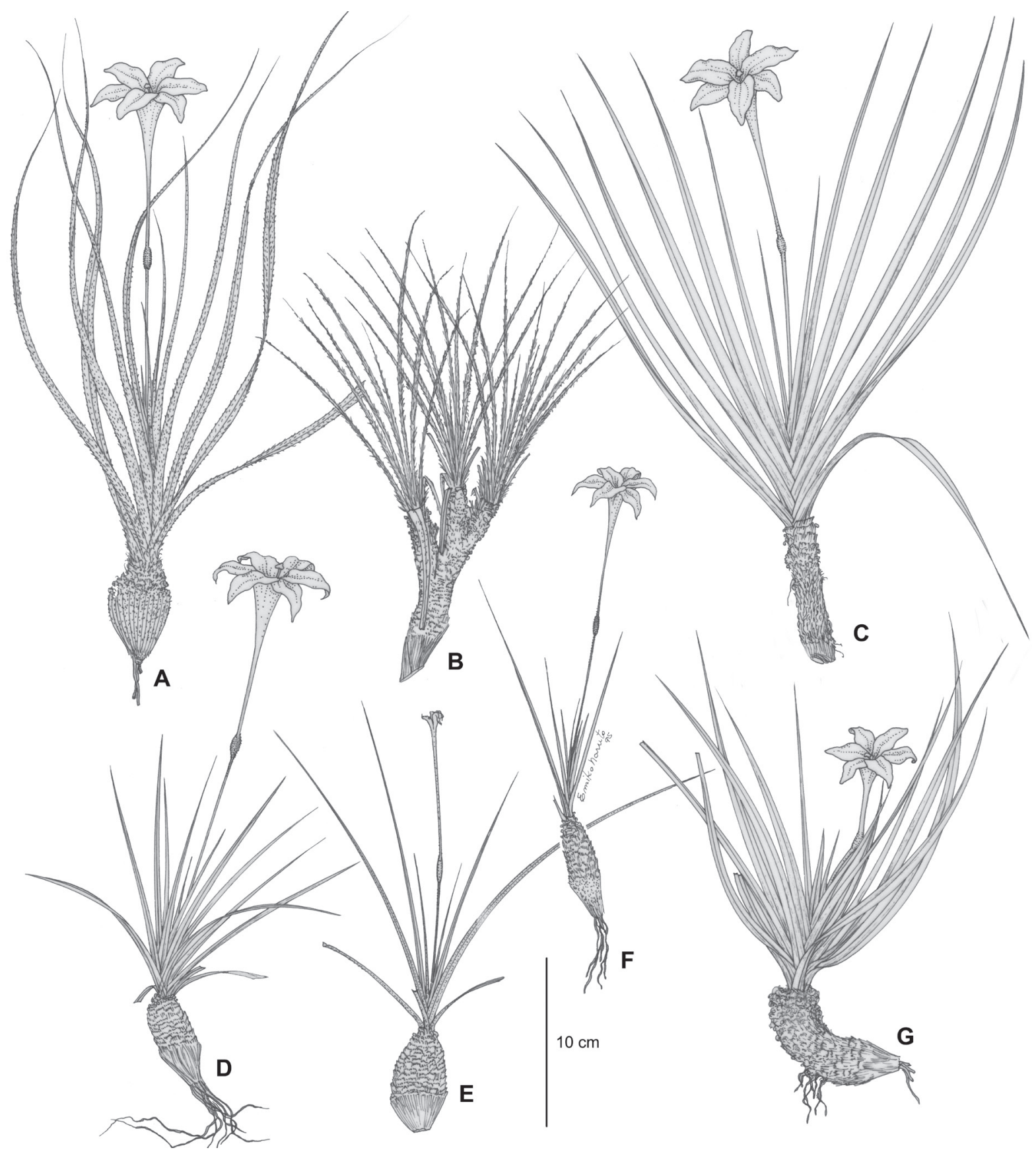

Figure 8. Patterns of V. tubiflora. A- B. Pattern 5. A. Glaziou 22219. B. Pohl s.n., M. C. Pattern 6 (Schultes 19120). D-G. Pattern 7. D. Heringer 17586. E. Semir 20642. F. Heringer 11320. G. Pires 6111. 


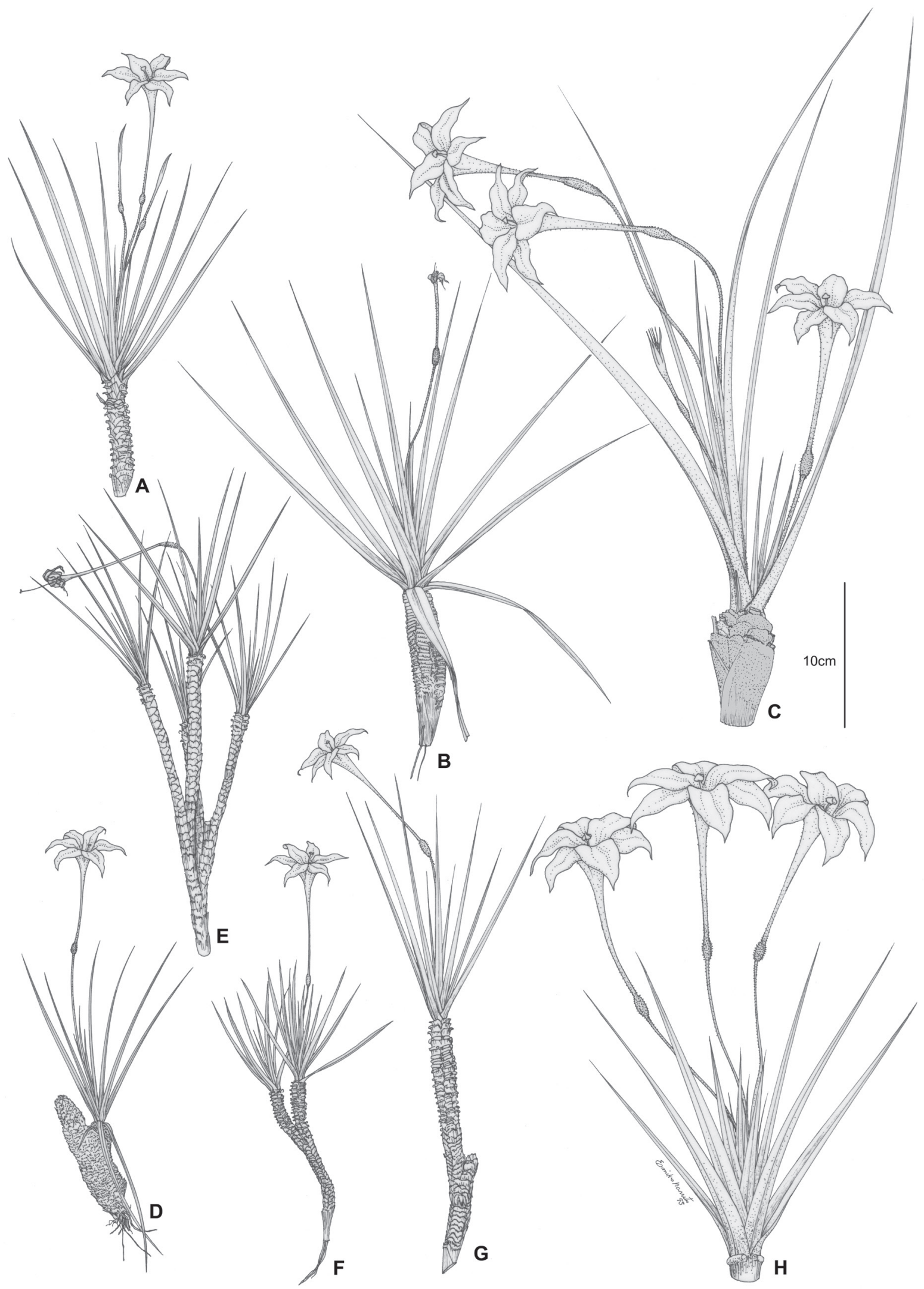

Figure 9. Patterns of V. tubiflora. A-H. Pattern 8. A. Pirani 1518. B. Harley 11417. C. Hatschbach 36801. D. Pirani 1871. E. Hatschbach 60296. F. Glaziou 22212, G. Pirani 1734. H. Dawson 14580. 
Distrito Federal, and in the Chapada dos Veadeiros mountains between Guaraí, to the north, and Caldas Novas, to the south. Disjunct populations are found in the Chapada Diamantina in Bahia State, in the localities of Abaíra (Ganev 623) and Piatã (MelloSilva CFCR7386); in Cachimbo farm (Cordeiro 1191) and Serra do Cachimbo (Nascimento 540) in Mato Grosso; and in Patrocínio (Irwin 25614) in Minas Gerais. In Bahia, the indumentum is extremely dense and woolly. Plowman 8291, from Tocantins State, shows leaf sheaths well spaced one from another, giving the plant an unique aspect. Hatschbach 58358, Ratter 45252, and Splett 277 possess all of the characteristics of this pattern, although the dry leaves are involute, typical of plants of pattern 8 . Ule 3142 (type specimen of $V$. macrosiphonia) could not be located, but to judge by the locality where it was collected, as well as from its description, it must belong to this pattern.

Pattern 6 - (Boyan 7, 22; García-Barriga 13804; Maguire 29156 [NY], 32307, 43855, 45918; Pipoly 7783; Pires 15053; Steyermark 117231, 125834, Schultes 13350, 15050a, 19120; figure 8C). Includes the types of $V$. dumitiana and $V$. maudeana. The plants are notable for their almost glabrous leaves, sometimes ciliated only at base. They occur in Colombia in the cerro Isibukuri; in Venezuela, in cerro Duida (e.g. Maguire 29156) and nearby along the Cunucunuma river (e.g. Steyermark 125834); in Brazil, they occur in Serra do Aracá (Pires 15053), and along the upper stretches of the Mazaruni river in Guyana (e.g. Boyan 7). Along this same river are found populations of the pattern 2. Maguire 29156 (NY) as well as Steyermark 117231 and 125834 are intermediate between this pattern and pattern 1 . Pattern 7 - (Arbo 3319; Hatschbach 36392, 51809; Heringer 9606, 11320, 17586; Meira Neto 20007; Mello-Silva 556; Menezes 776, 1004; Morellato 19936; Oliveira HUFU 2878; Pirani 1615; Pires 6111, 6232, 6235; Rizzo 7242; Semir 20530, 20455, 20642; figure 8D-G). Plants from Cristalina and Serra dos Pirineus, in Goiás State, Brazil. They are characterized by the medium or small habit, with stems from 9 to $30 \mathrm{~cm}$ long, and a diameter of 2-3 $\mathrm{cm}$ at the apex; the leaves are pubescent, rarely glabrous, with indumentum very short, the adaxial side is generally glabrous. They are similar to the plants of pattern 5, differing only in the length of the foliar trichomes. Collections from the Serra do Cachimbo, Pará State (V. cachimbensis) also adhere

Table 2. Collections of pattern 8 of Vellozia tubiflora, showing variation on flower colour and dimensions of individuals.

\begin{tabular}{|c|c|c|c|}
\hline Collection & Flower colour & Height (cm) & Width $(\mathrm{mm})$ \\
\hline Pirani 1871 & White & $10-30$ & 18 \\
\hline Hatschbach 60296 & White & 50 & 8 \\
\hline Prance 58275 & ? (Fruit) & 50 & 9 \\
\hline Azevedo 501 & White & 60 & 30 \\
\hline Prance 58276 & White & $50-100$ & 30 \\
\hline Glaziou 22212 & White & Shrub & 11 \\
\hline Irwin 12622 & White & 100 & 31 \\
\hline Mello-Silva 554 & ? (Fruits) & 100 & 18 \\
\hline Pereira 1518 & White & 120 & 15 \\
\hline Pirani 1734 & White & $40-150$ & 15 \\
\hline Cavalcanti 405 & White & 150 & 31 \\
\hline Hatschbach 36801 & White & 150 & 44 \\
\hline Irwin 12648 & White & 150 & 18 \\
\hline Cavalcanti 380 & White to light lilac & $?$ & 18 \\
\hline Hatschbach 60298 & White to light lilac & 100 & 28 \\
\hline Anderson 6380 & Lavender & 150 & 21 \\
\hline Oliveira 500 & Lilac & 200 & 22 \\
\hline Hatschbach 36869 & Violet & 150 & 23 \\
\hline Menezes 600 & Purple & 200 & 19 \\
\hline Menezes 599 & Purple & 200 & 16 \\
\hline Rizzo 8128 & Purple & $?$ & 18 \\
\hline Harley 11417 & Deep purple & 200 & 23 \\
\hline
\end{tabular}


Table 3. Herbarium specimens with flowers and fruits, during the year. Specimens of $V$. tubiflora are indicated according to their origin, either north $(\mathrm{N})$ or south $(\mathrm{S})$ of the equator.

\begin{tabular}{|c|c|c|c|c|c|c|c|c|c|c|c|c|c|c|c|}
\hline & & & Jul & Ago & Sep & Oct & Nov & Dec & Jan & Feb & Mar & Apr & May & Jun & Total \\
\hline \multirow{2}{*}{ V. hirsuta } & & $\mathrm{fl}$ & 2 & & 1 & 8 & 13 & 8 & 5 & 6 & 1 & 2 & & 2 & 48 \\
\hline & & fr & & 1 & & & 5 & 2 & 9 & 6 & 3 & 3 & 2 & 2 & 33 \\
\hline \multirow{4}{*}{ V.tubiflora } & \multirow{2}{*}{$\mathrm{N}$} & fl & 4 & 4 & 5 & 5 & 4 & 2 & 4 & 2 & 3 & 4 & 5 & 5 & 47 \\
\hline & & fr & 2 & 4 & 2 & 3 & 7 & 4 & 8 & 8 & 5 & 4 & 5 & 7 & 59 \\
\hline & \multirow[b]{2}{*}{$\mathrm{S}$} & fl & & & & 1 & 4 & 15 & 19 & 37 & 12 & 1 & 2 & 1 & 92 \\
\hline & & fr & 5 & 3 & 1 & 1 & & 5 & 5 & 10 & 6 & 1 & 2 & 1 & 40 \\
\hline
\end{tabular}

to this pattern, although these plants can reach up to 1.5 meters in height (Pires in sched.), which would better place them in pattern 1 . The populations of Serra dos Pirineus (e.g. Semir 20642, Menezes 1004), which have a slightly heavier indumentum, are intermediate between this pattern and pattern 5. The foliar anatomy of plants from Serra do Cachimbo is similar to the collection Rosa 2018, of the pattern 4. These differ from the remaining in that the fibre bundles on the adaxial leaf surface are exiguous or absent, and they have a large quantity of stomata on the adaxial surface. Rizzo 7242, of unknown origin, possesses all the characteristics of the plants from Cristalina, although their leaves are involute.

Pattern 8 - (Anderson 6380; Azevedo 501; Cavalcanti 380, 405, 1327, 1342; Dawson 14580; Duarte 10794; Glaziou 22212, 22217; Harley 11417, 11464; Hatschbach 36314, 36801, 36869, 36908, 60296, 60298; Irwin 12622, 12648, 24344; Mello-Silva 554; Menezes 273, 274, 599, 600, SPF 71864; Oliveira 500; Pereira 1518; Pirani 1824, 1734, 1871; Prance 58275, 58276; Rizzo 8128; Romaniuc Neto 635; figure 9A-H). Includes the types of $V$. annulata and $V$. dawsonii. The plants are characterized by flat leaves, which become involute when dried. This is the opposite of the majority of the individuals of other patterns, which have arched leaves that become revolute, or more rarely flat or involute, when dried. The indumentum is dense and short on the abaxial side of the leaf. Robust or very young individuals may have their basal leaves arched, although the rest of them will be flat. These populations are restricted to Chapada dos Veadeiros in the municipalities of Cavalcante, Alto Paraíso de Goiás and São João da Aliança, Goiás. Cavalcanti 1327, Harley 11464 , Hatschbach 36314, 36908, Irwin 24344, Menezes 274 and Pirani 1824 have flat or involute leaves, typical of this pattern, with indumentum similar to that found in pattern 5 and also in the plants from Serra dos
Pirineus (pattern 7). Cavalcanti 1342, which has a thin stem and leaves that become revolute when dry, is more similar to pattern 2, except for the indumentum, which is typical of pattern 8 . The plants of this pattern are considerably variable in size, which had leaded the authors to recognize two species, $V$. annulata and $V$. dawsonii. The first of these had been traditionally defined (Henrard 1937, Smith 1962, Smith \& Ayensu 1976) as a species approximately $50 \mathrm{~cm}$ tall, with slender stems and leaves, while the second species was more robust, up to 2 meters tall, with much more developed stems and leaves. However, there exists a gradient of variation in relation to this characteristic, with specimens ranging from $10 \mathrm{~cm}$ to 2 meters tall, without the existence of discrete categories within this range (Table 2). In relation to other attributes, the collections are identical. In terms of leaf anatomy, the collections exhibit gradation in the quantity and volume of the fibre bundles on the adaxial surface. These range from almost nonexistent in Glaziou 22212 and Dawson 14580 (type collections of $V$. annnulata and $V$. dawsonii, respectively, figure 10A, B), to well developed and numerous in Hatschbach 36801 and Prance 58276 (figure 10U, V). These collections can also present inconspicuous furrows (figure $10 \mathrm{~B})$. An anatomical characteristic of this pattern is the presence of an enlarged aquiferous parenchyma (figure 10A-D, F-S, U, V), although some individuals show a pattern similar to the general situation of the species (figure 10E, T). Glaziou 22212 has an inconspicuous palisade parenchyma (figure $1 \mathrm{~F}$ ), as in some populations of patterns 1 and 4 . All species of Vellozia once included in the section Radia (Smith \& Ayensu 1976) have white flowers, with only a very few individuals bearing purple flowers (Mello-Silva 2000). In this pattern 8 , the flowers range from white to deep violet, showing a gradient between the two extremes (table 2). 


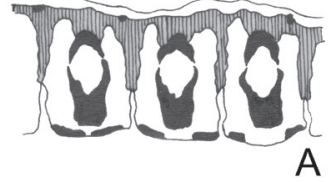

A

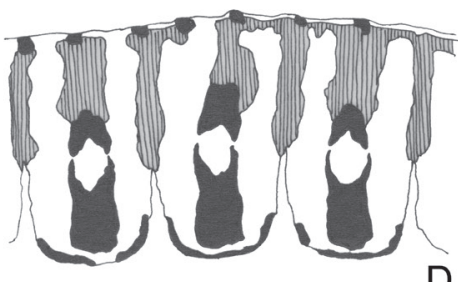

D
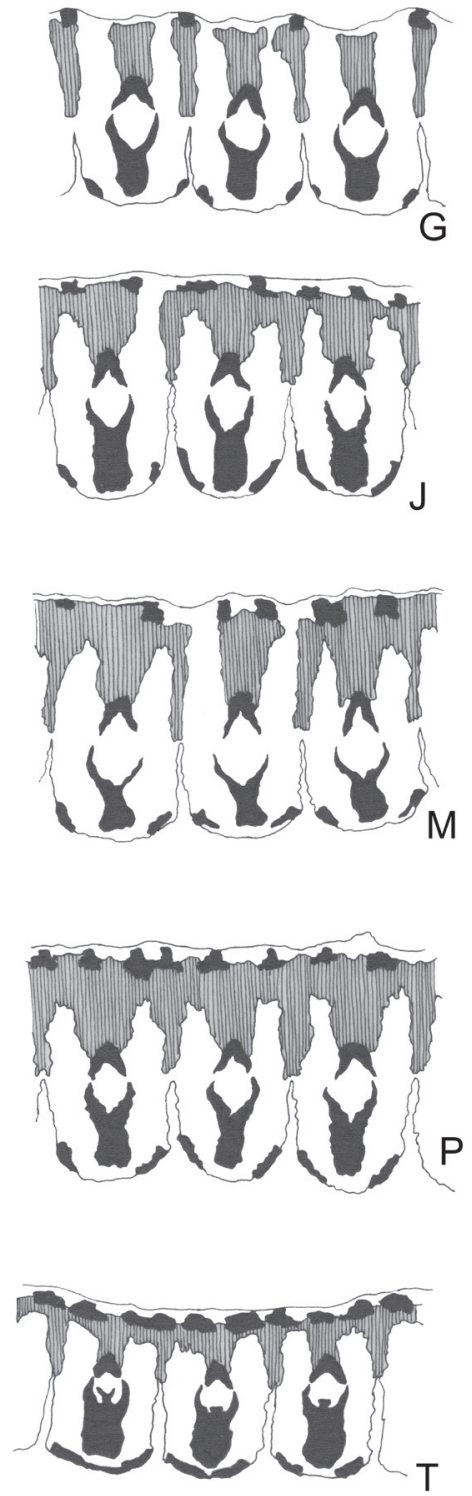

$1 \mathrm{~mm}$
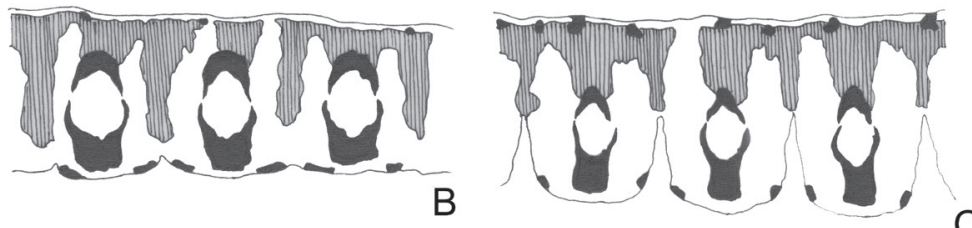

C
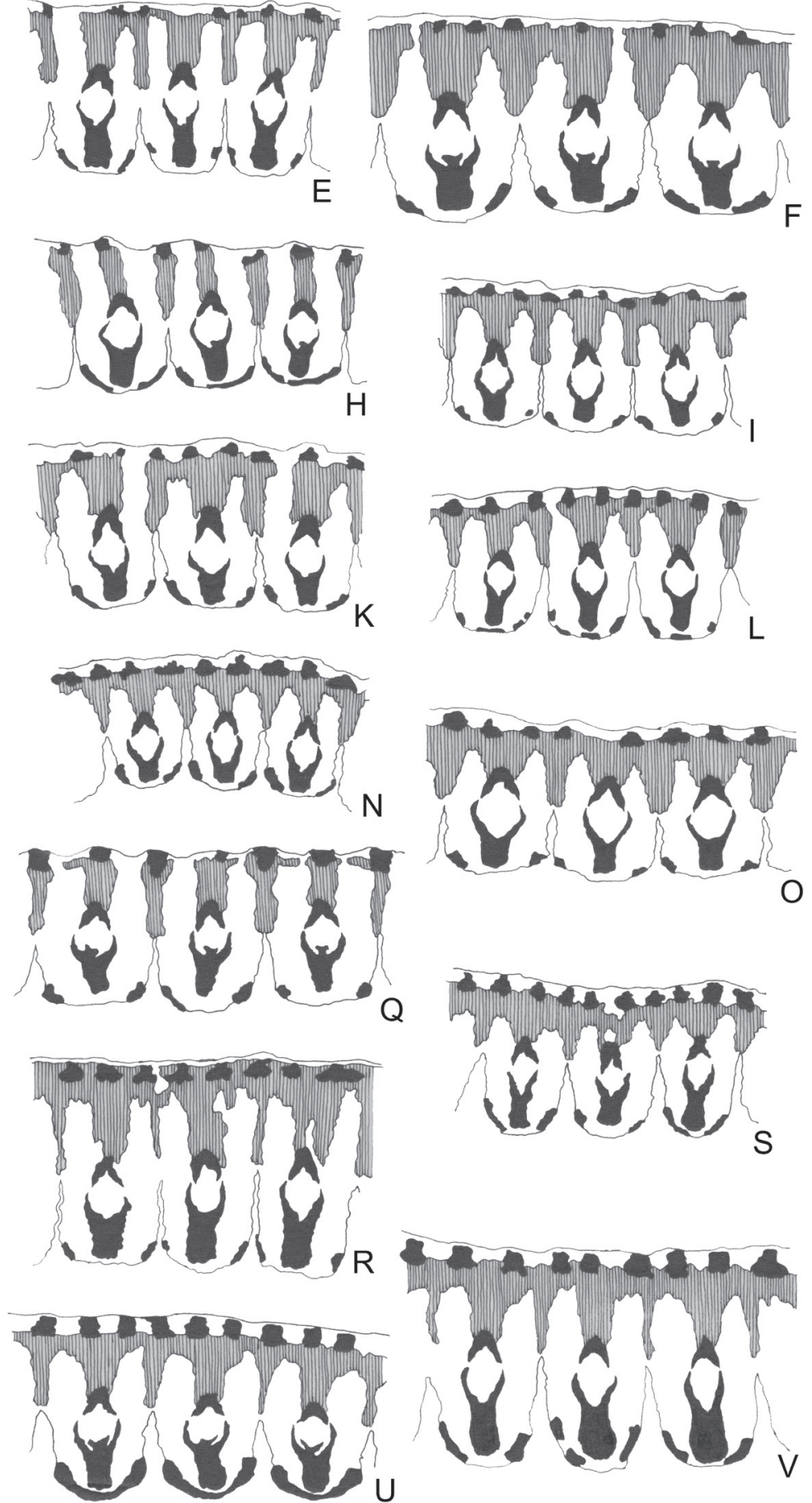

Figure 10. Transverse sections of mid portion of leaves of V. tubiflora, pattern 8, showing the distribution of sclerenchyma in black, and of aquiferous parenchyma, hatched. A. Glaziou 22212. B. Dawson 14580. C. Azevedo 501. D. Mello-Silva 554. E. Cavalcanti 380. F. Cavalcanti 405. G. Menezes SPF 71864. H. Pereira 1518. I. Menezes 599. J. Menezes 600. K. Menezes 273. L. Pirani 1871. M. Anderson 6380. N. Irwin 12648. O. Irwin 12622. P. Oliveira 500. Q. Irwin 24344. R. Hatschbach 36869. S. Rizzo 8128. T. Prance 58275. U. Hatschbach 36801. V. Prance 58276. 
Phenology - The large number of collections of $V$. hirsuta and $V$. tubiflora furnishes data concerning the modes of flowering and fruiting in these species (table 3). In V. tubiflora, there are two distinct groups with respect to flowering modes. The populations to the north of the equator show a flowering curve practically unaltered during the entire year, while the populations to the south of the equator have a distinct seasonal cycle, with flowering peaks between the months of December and February (table 3, figure 11B). $V$. hirsuta shows a flowering peak between October and January (table 3, figure 11A). Abiotic factors such as temperature, humidity and photoperiod may be acting in an isolated manner, or together, to produce these phenological patterns. Populations of $V$. tubiflora to the south of the equator, together with the populations of $V$. hirsuta, are situated in the South America zonobiome II, with evident seasonality of temperature and humidity, with heavy peak rains in the hot season, and an arid cold season (Walter 1984). These seasonal alterations in the climate seem to generate the type of flowering curves above mentioned, where the flowering peaks correspond to the wettest and warmest months. In contrast, the populations of $V$. tubiflora to the north of the equator are located for the most part in zonobiome I, in Venezuela and Colombia, or in the transition zone between zonobiomes I and II, in Venezuela, Guyana and Panama, where there is almost no seasonal climatic change (Walter 1984). The uniform climate could well be responsible for the uniformity in the flowering curve. The abiotic factors could influence flowering either directly, by altering the capacity of the plants to produce flowers, or indirectly, by effecting the pollination vectors (Rathcke \& Lacey 1985). In Central America, seasonal abundance of butterflies coincids with increased flowering of sphingophilous species. On the other hand, the seasonal increase in butterflies also coincids with production of new leaves, which are necessary for the development of their larvae (Janzen 1967, Frankie et al. 1974, Rathcke \& Lacey 1985), suggesting that the pollinator's life cycle is equally influenced by changes in the seasons. As both $V$. hirsuta and $V$. tubiflora are probably sphingophilous (Mello-Silva 1995, Sazima 1978, Vogel 1969a, b), this could be a factor effecting their flowering cycles. The influence of the photoperiod must also be considered. Plants may develop sensitivity to the small annual variations in day length (Daubenmire 1974). At $10^{\circ}$ of latitude the days can reach a length of 12 hours
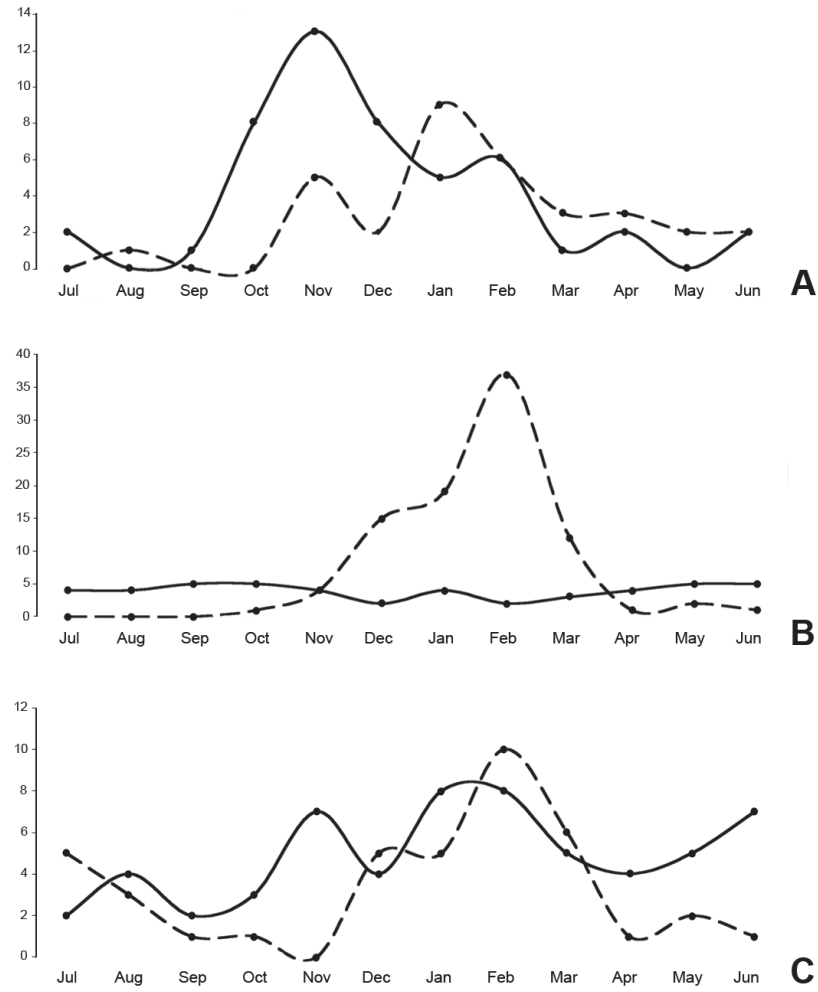

Figure 11. Herbarium specimens of $V$. hirsuta and $V$. tubiflora with flowers and fruits during the year. A. V. hirsuta, flowering specimens (continuous line) and fruiting specimens (dashed line). B. V. tubiflora, flowering specimens south of equator (dashed line) and north of equator (continuous line). C. V. tubiflora, fruiting specimens south of equator (dashed line) and north of equator (continuous line).

and 45 minutes and, at $20^{\circ}$, very near the southern limit of distribution of the species considered here (figure 2), daylight can last for up to 13 hours and 30 minutes (Salisbury \& Ross 1992). The species and populations demonstrating seasonal variations in flowering are exactly those found at greater latitudes; the populations of $V$. tubiflora showing persistent flowering throughout the year are located very near to the equator, where they experience only a small, or essentially nonexistent, differences in photoperiod. Phenological studies of populations situated at the extreme limits of distribution south of the equator (Serra das Flores, Ceará, and Serrana, São Paulo, both in Brazil) could help to clarify the influence of the photoperiod on flowering in these species.

Fruiting immediately follows flowering, thereby generating curves with similar patterns, although with a slight forward temporal dislocation (table 3 , 
figure $11 \mathrm{~A}, \mathrm{C})$. These results may be a bit imprecise, as the fruits remain attached to the plants for a long period, and their age was not taken into account in this study.

Biogeography (figure 2) - The diaspores of $V$. tubiflora, as well as the majority of the Vellozia, are not adapted for dispersion over long distances. This leads one to believe that $V$. tubiflora must have had, in the past, an essentially continuous distribution over the continent. Before the Miocene, the flora of the Brazilian and the Guyanan shields was continuous (Maguire 1970). This continuity was interrupted by three consecutive geological events which occurred about 3 million years ago: the rising up of the Andes Mountains, the elevation of the Guyanan plateau, and the resultant change in direction of the flow of the Amazon river (Brown \& Gibson 1983). The Amazon at first formed a lake, and then a river system, both of which allowed the installation of an Amazon flora, which served as a barrier between the flora of the mountains of Brazil and that of Guyana (Maguire 1970). Thus, the populations of $V$. tubiflora in South America were separated from those of Panama, as well as the populations north and south of the line of the equator. Later, the erosion of the highlands and cyclical climatic changes probably served to further fragment these once contiguous populations into three main blocks, as well as many smaller isolated populations. In the Espinhaço range, the fragmentation of an ancient plain by erosion (Abreu 1984) resulted in the isolation of resident populations of $V$. hirsuta. The absence of $V$. tubiflora in the greater part of the Espinhaço range is of importance to the biogeography of the region. Its probable ecological correspondent in the region is $V$. hirsuta. The two species are very similar with respect to their external morphological characteristics, and both are probably sphingophilous (Sazima 1978, Vogel 1969a, b). These similar characteristics have placed them closely related in morphological analyses (Mello-Silva 2000, 2005), but appeared as convergences in a combined analysis (Mello-Silva et al. unpublished data). The area of distribution of $V$. hirsuta in the Espinhaço range reaches the mountains in Macaúbas, Bahia State. Beyond the Paramirim and São Paulo river valleys, $V$. hirsuta is no longer found, only populations of $V$. tubiflora. In no other place they do come closer. In this way, the southern and western portions of the Espinhaço range in Bahia may be more closely related biogeographically to the elevations in Minas Gerais than with the bulk of the
Chapada Diamantina mountains that lie further to the northeast. If this statement is correct, the Paramirim, Rio de Contas, and São Paulo river valleys act as vicariant barriers.

Nomenclatural notes - Bellow are present nomenclatural and typification notes of some names involved in taxonomy of both Vellozia hirsuta and $V$. tubiflora.

\section{Vellozia annulata Goethart \& Henrard}

Goethart \& Henrard in Henrard (1937) designated Glaziou 22212 and 22217, mounted on a single sheet in the Leiden herbarium (L), as type collections (syntypi) of $V$. annulata. Smith \& Ayensu (1976) assigned only Glaziou 22212, which is also deposited in $\mathrm{BR}, \mathrm{K}$, and P herbaria, as the type collection. In this manner they effected the lectotypification, although they did not convey that.

\section{Vellozia riedeliana Goethart \& Henrard}

Goethart \& Henrard in Henrard (1937) designated Riedel 1051 at LE as holotype of $V$. riedeliana. Nevertheless, this number is not found at LE and a lectotype should be designated with the isotype housed at L.

\section{Vellozia tubiflora (A.Rich.) Kunth}

Richard used the name Campderia, in the Bull. Soc. Philom. in May of 1822, to describe two New World species of Velloziaceae: Campderia langsdorffii ('Langsderffii') and C. tubiflora. The work is an excerpt, in the third person, of a lecture given by the author to the Sociéte Philomatique de Paris in March of 1822. The name Campderia had already been given to a genus of Umbelliferae (Campderia Lag., Amen. Nat. Españas 2: 99. 1821 $=$ Kundemannia Scop.), becoming Campderia A.Rich. a later homonym, and therefore illegitimate (article 53.1, ICBN). Perhaps having become aware that the name had already been used in the Umbelliferae, Richard published, in the Syn. pl. of Kunth in December 9, 1822, Campderia as a generic synonym of Radia (Radia had also been used, in the Sapotaceae, but in this case it was a nomen nudum). If the name Radia was intended as homage to the botanist Raddi, it should be written as Raddia and thus be treated as an illegitimate later homonym of Raddia Bertol. (Bologn. Opusc. Sc. 3: 410. 1891). However, there is no evidence that Radia refers to Raddi and, as such, this generic name can be treated as legitimate. In conclusion, Campderia tubiflora is 
not the correct name (article 55.1, ICBN) and Radia tubiflora and Vellozia tubiflora should be based on it. In describing Campderia tubiflora, Richard (1822) used material collected by Humboldt and Bonpland on the banks of the Orinoco river, in May 1800. In proposing the combination for Radia tubiflora, Richard (in Kunth 1822) provided a short analysis of the species as well as a detailed description, this being based on a manuscript written by Bonpland. Kunth (1825) used the same procedure when transferring it to the genus Vellozia, noting that the type material had been destroyed (specimina suppetentia carie destructa). This material could not be located in the Paris herbarium (P). Humboldt (1980: 142) noted that many of Bonpland's collections that have been made during May 1800, along the banks of the Orinoco river, were lost due to excess humidity. Thus for the neo-typification of the species, a collection from that same region (Maguire 29245) was chosen. All populations along that river belong to pattern 1 described above.

Vellozia velutinosa Goethart \& Henrard

Goethart \& Henrard in Henrard (1937) designated Glaziou 22218 as type collection of $V$. velutinosa, but did not cite any herbaria. Smith \& Ayensu (1976) assigned a material in $\mathrm{L}$ as the holotype. However, Glaziou 22218 could not be found in that or in any other herbaria, except $\mathrm{K}$, and this has been chosen as lectotype.

\section{Acknowledgements}

This study is part of a $\mathrm{PhD}$ thesis submitted to the Institute of Biosciences of the University of São Paulo, under the supervision of Ana Maria Giulietti. Thanks are due to the following herbaria for sending specimens to SPF: A, B, BONN, CEN, COL, EAC, F, GH, HB, HRB, HRCB, IBGE, INPA, K, L, M, MBM, MG, MO, NY, P, R, RB, RFA, S, SP, UB, UEC, UFG, US, USZ, and W; to the institutions that made this work possible, CAPES, CNPq, FAPESP and University of São Paulo; to Margaret Mee Amazonian Trust and Andrew W. Mellon Latin America Botanical Fellowship (KLARF) for funding studies at the Royal Botanic Gardens, Kew, and visits to $\mathrm{B}, \mathrm{BM}, \mathrm{BR}, \mathrm{L}, \mathrm{M}, \mathrm{OXF}$, and $\mathrm{P}$ herbaria; to the persons responsible for the Anatomy Laboratory of the Department of Botany and the Electronic Microscopy Laboratory of the Institute of Biosciences; to Ana Maria Giulietti, Nanuza Menezes, José Pirani, Maria
Luiza and Antonio Salatino, Simon Mayo, Eimear Nic Lughadha, Nigel Taylor, Taciana Cavalcanti, Volker Bittrich, Hilda Longhi-Wagner, João Semir, Mário de Pinna and Antônio Marques for discussions and suggestions, to Alessandro Rapini for critical reading, to Juliana Lovo for helping with the figures, and to Emiko Naruto (in memoriam) for the drawings. The author has a CNPq research fellowship.

\section{Literature cited}

Abreu, A.A. 1984. O Planalto de Diamantina: um setor da Serra do Espinhaço em Minas Gerais. Orientação - Instituto de Geografia, USP. São Paulo, v. 5, pp. 75-79.

Ayensu, E.S. 1974. Leaf anatomy and systematics of New World Velloziaceae. Smithsonian Contributions to Botany 15: i-vi + 1-125.

Behnke, H.-D., Treutlein, J., Wink, M., Kramer, K., Schneider, C. \& Kao, P.C. 2000. Systematics and evolution of Velloziaceae, with special reference to sieve-element plastids and $r b c \mathrm{~L}$ sequence data. Botanical Journal of the Linnean Society 134: 93-129.

Brown, J.H \& Gibson, A.C. 1983. Biogeography. C. V. Mosby, St. Louis.

Daubenmire, R.F. 1974. Plants and environment. 3 ed. John Wiley \& Sons, New York.

Frankie, G.W., Baker, H.G. \& Opler, P.A. 1974. Comparative phenological studies of trees in tropical wet and dry forests in the lowlands of Costa Rica. Journal of Ecology 62: 881-913.

Giulietti, A.M. \& Pirani, J.R. 1988. Patterns of geographic distribution of some plant species from the Espinhaço range, Minas Gerais and Bahia, Brazil. In: W.R. Heyer \& P.E. Vanzolini (eds.). Proceedings of a workshop on Neotropical distribution patterns. Academia Brasileira de Ciências, Rio de Janeiro, pp. 39-69.

Henrard, J.T. 1937. Velloziaceae americanae nonnullae novae vel minus cognitae. Blumea 2: 339-384.

Holmgren, P.K. \& Holmgren, N.H. 1998 (continuously updated). Index herbariorum: A global directory of public herbaria and associated staff. New York Botanical Garden's Virtual Herbarium. http://sweetgum.nybg.org/ ih. (access ed in 25.8.2009)

Humboldt, F.W.H.A. 1980. Voyages dans l'Amérique équinoxiale. 1. Itinéraire. François Maspero, Paris. 
Janzen, D.H. 1967. Synchronization of sexual reprodution of trees within the dry season in Central America. Evolution 21: 620-637.

Kunth, C.S. 1822. Synopsis plantarum. v. 1 F. G. Levrault, Paris.

Kunth, C.S. 1825. Vellozia tubiflora. In: F.W.H.A. Humboldt, A.J.A. Bonpland \& C.S. Kunth (eds.). Nova genera et species plantarum. Gide, Paris, v. 7(32), pp. 155.

Luque, R., Souza, H.C. \& Kraus, J.E. 1996. Métodos de coloração de Roeser (1972) - modificado - e Kropp (1972) visando a substituição do azul de astra pelo azul de alcião $8 \mathrm{GS}$ ou $8 \mathrm{GX}$. Acta Botanica Brasilica 10: 199-212.

Maguire, B. 1969. The botany of the Guayana Highland - Part VIII. Velloziaceae. Memoirs of The New York Botanical Garden 18: 32-41.

Maguire, B. 1970. On the flora of the Guayana Highland. Biotropica 2: 85-100.

Mello-Silva, R. 1990. Morphological and anatomical differentiation of Vellozia hirsuta populations (Velloziaceae). Plant Systematics and Evolution 173: 197-208.

Mello-Silva, R. 1995. Aspectos taxonômicos, biogeográficos, morfológicos e biológicos das Velloziaceae de Grão-Mogol, Minas Gerais, Brasil. Boletim de Botânica da Universidade de São Paulo 14: 49-79.

Mello-Silva, R. 2000. Partial cladistic analysis of Vellozia and characters for the phylogeny of Velloziaceae. In: K.L. Wilson \& D.A. Morrison (eds.). Monocots: Systematics and evolution. Csiro, Melbourne, pp. 505-522.

Mello-Silva, R. 2005. Morphological analysis, phylogenies, and classification in Velloziaceae. Botanical Journal of the Linnean Society 148: 157-173.

Menezes, N.L. 1980. Evolution in Velloziaceae with special reference to androecial characters. In: C.D. Brickell, D.F. Cutler \& M. Gregory (eds.).
Petaloid Monocotyledons: horticultural and botanical research. Academic Press, London, pp. 117-139.

Rathcke,B.\& Lacey,E.P.1985.Phenological patterns of terrestrial plants. Annual Review of Ecology and Systematics. Harper \& Row, New York.

Richard, A. 1822. Mémoire sur le Campderia, genre nouveau de la famille des Bromeliacées. Bulletin des Sciences par la Société Philomatique de Paris 1822: 79.

Roeser, K.-R. 1972. Die Nadel der Schwarzkiefer - Massenprodukt und Kunstwerk der Natur. Mikrokosmos 61: 33-36.

Salisbury, F.B. \& Ross, C.W. 1992. Plant phyysiology. 4 ed. Wadsworth Publishing Company, Belmont.

Sazima, M. 1978. Biologia floral de espécies de Velloziaceae na Serra do Cipó, Minas Gerais. Tese de Doutorado, Universidade de São Paulo, São Paulo.

Simpson, B.B. \& Neff, J.L. 1985. Plants, their pollinating bees, and the great American interchange. In: F.G. Stehli \& S.D. Webb (eds.). The great American biotic interchange. Plenum Press, New York, pp. 427- 452.

Smith, L.B. 1962. A synopsis of the American Velloziaceae. Contributions from the United States National Herbarium 35: 251-292, pl. 1-12.

Smith, L.B. \& Ayensu, E.S. 1976. A revision of American Velloziaceae. Smithsonian Contributions to Botany 30: i-viii + 1-172.

Sousa, M.S. 2005. Morfogênese de frutos e sementes de Velloziaceae. Dissertação de Mestrado, Universidade de São Paulo, São Paulo.

Vogel, S. 1969a. Chiropterophilie in der neotropischen Flora. Neue Mitteilungen 2. Flora 158: 185-222.

Vogel, S. 1969b. Chiropterophilie in derneotropischen Flora. Neue Mitteilungen 3. Flora 158: 289-323.

Walter, H. 1984. Vegetation und Klimazonen. Grundriss der globalen Ökologie. Eugen Ulmer, Stuttgart. 